Aquatic Plant Control Research Program

\title{
Aquatic Vegetation Restoration in Arcadia Lake, Oklahoma: A Case Study
}

Gary Owen Dick, R. Michael Smart, and Eugene R. Gilliland May 2004

US Army Corps of Engineers ${ }_{\circledast}$

Engineer Research and Development Center

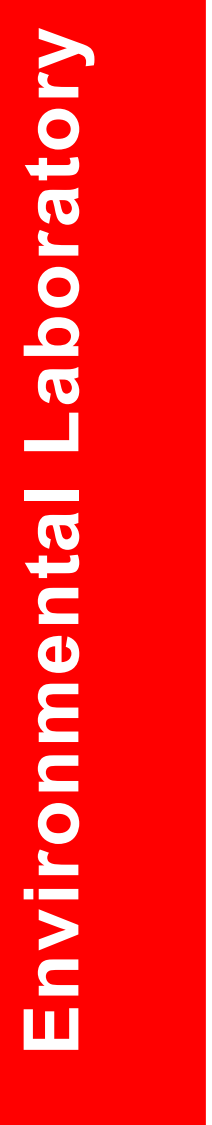




\section{Aquatic Vegetation Restoration in Arcadia Lake, Oklahoma: A Case Study}

Gary Owen Dick, R. Michael Smart, Eugene R. Gilliland

Lewisville Aquatic Ecosystem Research Facility

U.S. Army Engineer Research and Development Center

201 E. Jones Street

Lewisville, TX 75057

Final report

Approved for public release; distribution is unlimited 


\begin{abstract}
Arcadia Lake is located within the metropolitan area of Oklahoma City and Edmund, in Oklahoma County, Oklahoma, about 2.4 km (1.5 miles) southwest of Arcadia, Oklahoma (Figure 1). Construction of the earth-filled dam was authorized by the Flood Control Act of 1970 and approved for construction by the Secretary of the Army for the purposes of flood control, water supply, and recreation. Construction was completed in 1986, and conservation pool was reached in 1989. The dam impounds a section of the Deep Fork River, with drainage coming principally from surrounding municipalities. The reservoir covers approximately $736 \mathrm{ha}(1,820$ acres $)$ at an elevation of $307 \mathrm{~m}(1,006 \mathrm{ft}) \mathrm{msl}$ at conservation pool, with the top of its flood control pool at elevation $320 \mathrm{~m}(1049 \mathrm{ft}) \mathrm{msl}$.
\end{abstract}

The overall objective of the project was to begin restoration of spawning and nursery fishery habitat for the sunfish family (largemouth bass, crappie, and bluegill) lost from flood control operations. When initially impounded, flooded terrestrial structure provided good habitat for the sunfish fishery. As flood control operations were implemented, habitat structure (primarily flooded tress and brush) degraded, leaving the lake poorly suited for this fishery. The loss of structure also contributed to increases in turbidity, further affecting the sunfish fishery.

The specific objectives of the project were to (a) evaluate the suitability of selected native emergent, floating-leaved, and submersed aquatic species for establishment in the lake, (b) ascertain effective methods for establishing desirable aquatic plant species, and (c) establish founder colonies of aquatic plants in several areas of the lake. In addition to providing immediate nursery habitat for juvenile fish, these founder colonies were expected to provide propagules for natural spread to other areas of the lake.

DISCLAIMER: The contents of this report are not to be used for advertising, publication, or promotional purposes. Citation of trade names does not constitute an official endorsement or approval of the use of such commercial products. All product names and trademarks cited are the property of their respective owners. The findings of this report are not to be construed as an official Department of the Army position unless so designated by other authorized documents. 


\section{Contents}

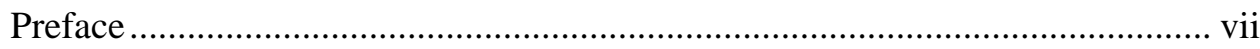

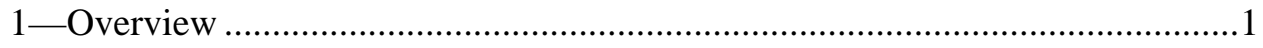

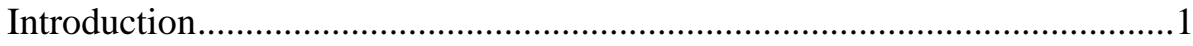

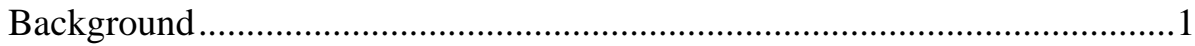

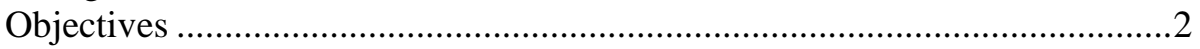

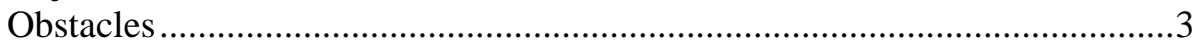

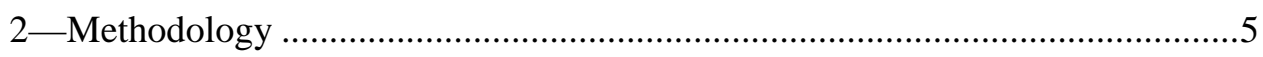

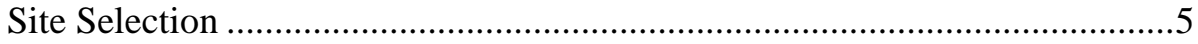

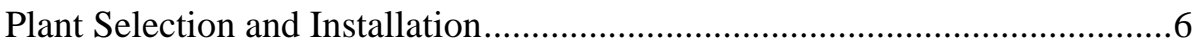

Exclosure Construction and Planting Designs ...............................................

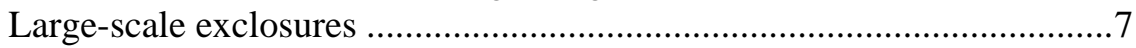

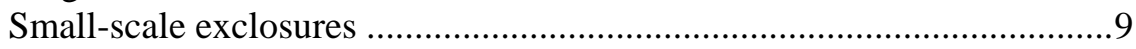

Assessments and Additional Planting .........................................................11

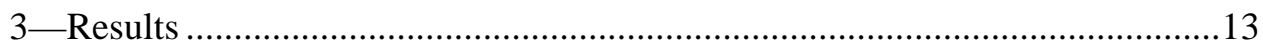

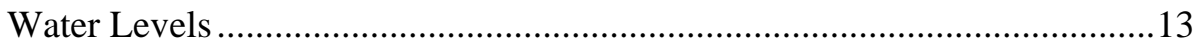

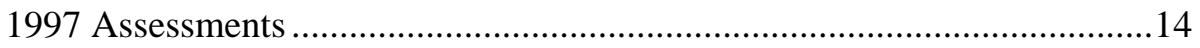

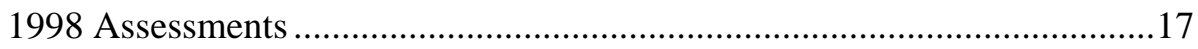

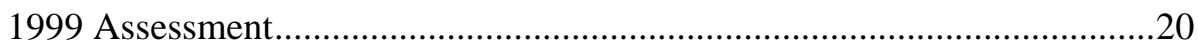

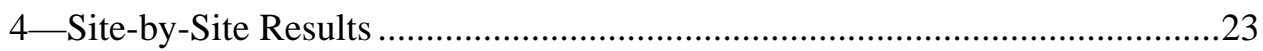

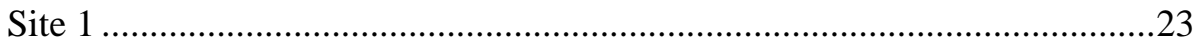

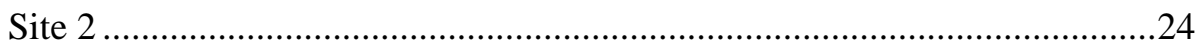

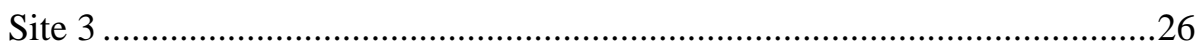

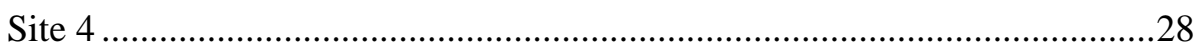

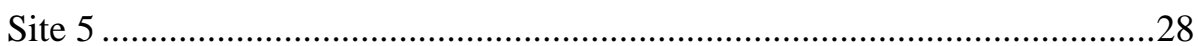

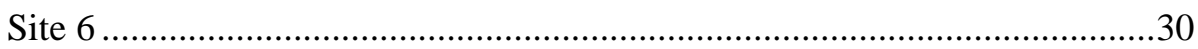

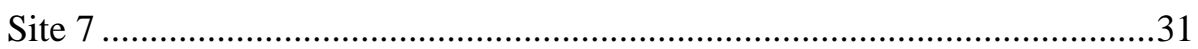

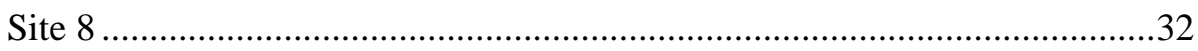

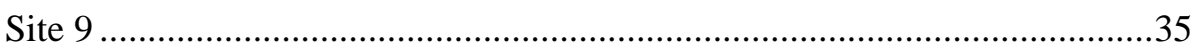

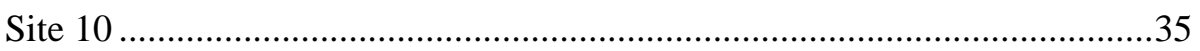

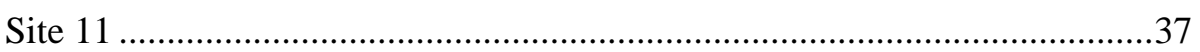

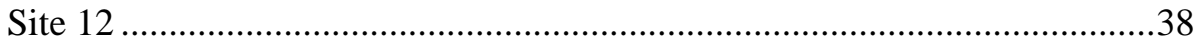

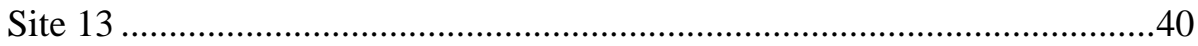

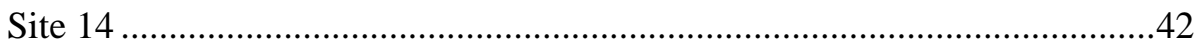

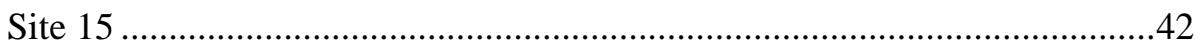




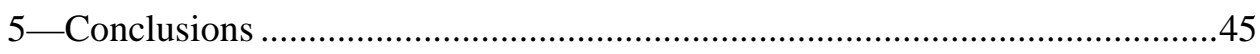

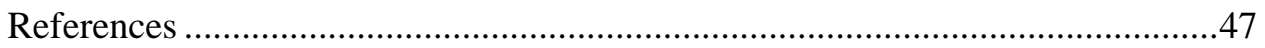

Appendix A: 2001 Assessment ....................................................................A1

SF 298

\section{List of Figures}

Figure 1. Arcadia Lake is located in Oklahoma County, Oklahoma, just north of Oklahoma City ......................................2

Figure 2. Arcadia Lake water level elevations between 1985 and 1995, before implementation of aquatic plant establishment efforts. 3

Figure 3. Fifteen sites were selected for aquatic plant founder colony establishment in Arcadia Lake

Figure 4. Various large- and small-scale protective exclosures were constructed in Arcadia Lake to reduce herbivore pressure on aquatic plants

Figure 5. Tomato cages served as small-scale protection for individual plants in Arcadia Lake .....

Figure 6. Orange cages served as small-scale protection for small sets of plants in Arcadia Lake

Figure 7. Plant and colony size estimates were made by (a) measuring colony length, (b) measuring colony width, (c) averaging length and width, and (d) recording as diameter. .12

Figure 8. Arcadia Lake water levels fluctuated significantly from conservation pool (307 m msl (1,006 ft msl)) during 1997 and 1998

Figure 9. Fluctuating water levels apparently affected submersed and floating-leaved plant survival in tomato cages .15

Figure 10. GPS mapping of aquatic plant colonies and protective exclosures was conducted at Site 1 in Arcadia Lake in June 1999

Figure 11. GPS mapping of aquatic plant colonies and protective exclosures was conducted at Site 2 in Arcadia Lake in June 1999 .26 
Figure 12. GPS mapping of aquatic plant colonies and protective exclosures was conducted at Site 3 in Arcadia Lake in June 1999

Figure 13. GPS mapping of aquatic plant colonies and protective exclosures was conducted at Site 4 in Arcadia Lake in June 1999

Figure 14. GPS mapping of aquatic plant colonies and protective exclosures was conducted at Site 5 in Arcadia Lake in June 1999 .30

Figure 15. GPS mapping of aquatic plant colonies and protective exclosures was conducted at Site 6 in Arcadia Lake in June 1999

Figure 16. GPS mapping of aquatic plant colonies and protective exclosures was conducted at Site 7 in Arcadia Lake in June 1999 .33

Figure 17. GPS mapping of aquatic plant colonies and protective exclosures was conducted at Site 8 in Arcadia Lake in June 1999

Figure 18. GPS mapping of aquatic plant colonies and protective exclosures was conducted at Site 9 in Arcadia Lake in June 1999 .36

Figure 19. GPS mapping of aquatic plant colonies and protective exclosures was conducted at Site 10 in Arcadia Lake in June 1999

Figure 20. GPS mapping of aquatic plant colonies and protective exclosures was conducted at Site 11 in Arcadia Lake in June 1999

Figure 21. GPS mapping of aquatic plant colonies and protective exclosures was conducted at Site 12 in Arcadia Lake in June 1999

Figure 22. GPS mapping of aquatic plant colonies and protective exclosures was conducted at Site 13 in Arcadia Lake in June 1999

Figure 23. GPS mapping of aquatic plant colonies and protective exclosures was conducted at Site 14 in Arcadia Lake in June 1999 .43

Figure 24. GPS mapping of aquatic plant colonies and protective exclosures was conducted at Site 15 in Arcadia Lake in June 1999 
Figure A1. GPS mapping of aquatic plant colonies and protective exclosures was conducted at Site 4 in Arcadia Lake in June 2001

Figure A2. GPS mapping of aquatic plant colonies and protective exclosures was conducted at Site 6 in Arcadia Lake in June 2001

\section{List of Tables}

Table 1. Twenty-Two Native Aquatic Plant Species Were Planted in Arcadia Lake in 1997 and 1998

Table 2. $\quad$ Large-Scale Protective Exclosures Were Constructed and/or Modified at Most of the 15 Sites in Arcadia Lake during 1997 and 1998.

Table 3. Arcadia Lake Restoration Sites and Small-Scale Protective Exclosures Constructed at Each

Table 4. Percent Survival of Aquatic Plants Species and Ecotypes Protected by Small-scale Exclosures and not Protected by Small-scale Exclosures During 1997

Table 5. Survival of Submersed Aquatic Plant Species Protected by Pens during 1997.

Table 6. Number of Aquatic Plant Colonies Surviving at the End of the 1998 Growing Season in Arcadia Lake

Table 7. Species That Appeared to be Established in Arcadia Lake after Two Growing Seasons

Table 8. $\quad$ Colonies (by species) Observed in June 1999 at 15 Sites in Arcadia Lake .22 


\section{Preface}

The work reported herein was conducted as part of the Aquatic Plant Control Research Program (APCRP), Work Unit 33084. The APCRP is sponsored by Headquarters, U.S. Army Corps of Engineers (HQUSACE), and is assigned to the U.S. Army Engineer Research and Development Center (ERDC) under the purview of the Environmental Laboratory (EL). Funding was provided under Department of the Army Appropriation Number 96X3122, Construction General. Mr. Robert C. Gunkel, Jr., EL, ERDC, was Program Manager, APCRP. Program Monitor during this investigation was Mr. Timothy R. Toplisek, HQUSACE.

Principal Investigator for this study was Dr. R. Michael Smart, Ecosystem Processes and Effects Branch (EPEB), Environmental Processes and Effects Division (EPED), EL. The report was prepared by Dr. Smart, assisted by Dr. Gary O. Dick, assigned to EPED under an Intergovernmental Personnel Act Agreement with the Institute of Applied Sciences, University of North Texas, Denton, TX, and Dr. Eugene U. Gilliland, Fisheries Biologist with the Oklahoma Department of Wildlife Conservation, Norman, Ok. The report was reviewed by Mr. Joe R. Snow, Ecology and Environmental Engineering Division, EL, and contractor with AScI, and Ms. Chetta S. Owens, AScI.

This work was performed under the general supervision of Dr. Elizabeth Fleming, Acting Director, EL; and Dr. Richard Price, Chief, EPED.

COL James R. Rowan, EN, was Commander and Executive Director of ERDC. Dr. James R. Houston was Director. 


\section{Overview}

\section{Introduction}

Aquatic plants, including submersed aquatic plants, play important roles in aquatic systems. They improve water clarity and quality (James and Barko 1990) and reduce rates of shoreline erosion and sediment resuspension (James and Barko 1995). Further, aquatic plants provide valuable fish and wildlife habitat (Dibble et al. 1996) and serve as a food source for waterfowl and aquatic mammals. Native aquatic plants also help prevent spread of nuisance exotic plants (Smart et al. 1994): this role has been of primary interest to the Aquatic Plant Control Research Program (APCRP).

Because the research on aquatic plant establishment that was conducted under the APCRP represented the current "state of the art" (Smart et al. 1996), the Tulsa District solicited our involvement in the planning and implementation of a Section 1135 project to establish aquatic plants for fish habitat enhancement in Arcadia Lake, Oklahoma. Because there is still much to learn regarding establishment of beneficial native plants, we elected to participate in this project and to incorporate some testing and data collection in an attempt to further advance the science. This report documents the restoration project and describes what we learned in the process.

\section{Background}

Arcadia Lake is located within the metropolitan area of Oklahoma City and Edmund, in Oklahoma County, Oklahoma, about $2.4 \mathrm{~km}$ (1.5 miles) southwest of Arcadia, Oklahoma (Figure 1). Construction of the earth-filled dam was authorized by the Flood Control Act of 1970 and approved for construction by the Secretary of the Army for the purposes of flood control, water supply, and recreation. Construction was completed in 1986 and conservation pool was reached in 1989. The dam impounds a section of the Deep Fork River, with drainage coming principally from surrounding municipalities. The reservoir covers approximately 736 ha (1,820 acres) at an elevation of $307 \mathrm{~m}(1,006 \mathrm{ft})$ mean sea level (msl) at conservation pool, with the top of its flood control pool at elevation $320 \mathrm{~m}(1049 \mathrm{ft}) \mathrm{msl}$. 


\section{Oklahoma County, Oklahoma}

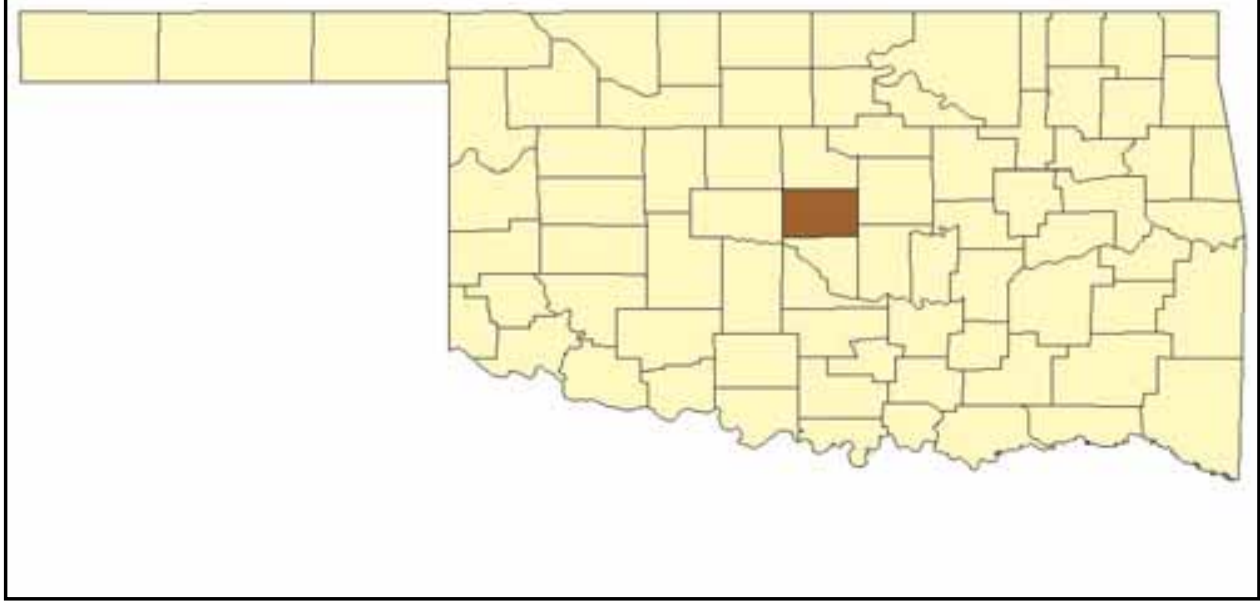

Figure 1. Arcadia Lake is located in Oklahoma County, Oklahoma, just north of Oklahoma City

Habitat restoration was conducted in Arcadia Lake between 1996 and 1998. U.S. Army Corps of Engineer District, Tulsa, Oklahoma Department of Wildlife Conservation (ODWC), and the USACE Lewisville Aquatic Ecosystem Research Facility worked together to develop and implement the project, which was 75-percent funded under the authority of Section 1135(b) of the Water Resources Development Act of 1986, PL 99-662, as amended. In this type project, the Secretary of the Army may review civil works projects constructed by the USACE to determine need to modify structure or operation for the purpose of improving the quality of the environment in the public interest. ODWC served as the local sponsor and provided 25 percent cost-share funding, principally in the manner of in-kind labor and materials.

\section{Objectives}

The overall objective of the project was to begin restoration of spawning and nursery fishery habitat for the sunfish family (largemouth bass, crappie, and bluegill) lost from flood control operations. When initially impounded, flooded terrestrial structure provided good habitat for the sunfish fishery. As flood control operations were implemented, habitat structure (primarily flooded tress and brush) degraded, leaving the lake poorly suited for this fishery. The loss of structure also contributed to increases in turbidity, further affecting the sunfish fishery. 
The specific objectives of the project were to (a) evaluate the suitability of selected native emergent, floating-leaved, and submersed aquatic species for establishment in the lake, (b) ascertain effective methods for establishing desirable aquatic plant species, and (c) establish founder colonies of aquatic plants in several areas of the lake. In addition to providing immediate nursery habitat for juvenile fish, these founder colonies were expected to provide propagules for natural spread to other areas of the lake.

\section{Obstacles}

Establishment of aquatic vegetation was expected to meet with two major obstacles: (a) water level fluctuations and (b) herbivory. Historically, water levels in the lake exceed conservation pool during late spring or early summer, and have risen by as many as $4.9 \mathrm{~m}$ (16 ft) during those times (Figure 2). These spikes have been short-lived, with floodwater release returning the lake to conservation pool within several weeks. Conversely, water levels in the lake have not fallen below conservation pool by more than $0.3 \mathrm{~m}(1 \mathrm{ft})$ in any given year. Duration of low-water conditions has been variable, with recovery dependent upon rainfall in the watershed.

\section{Arcadia Lake Elevations (1989-1995) 7 Day Intervals}

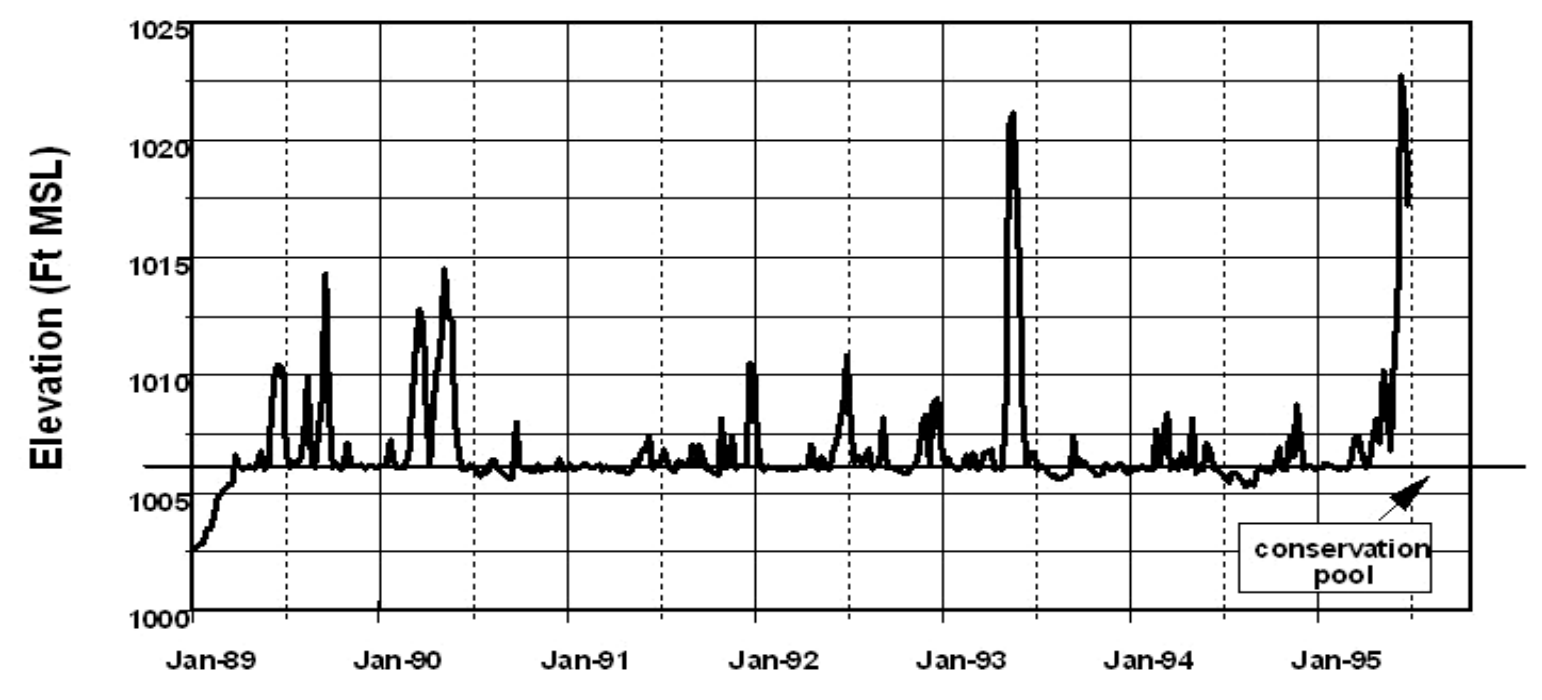

\section{Date}

Figure 2. Arcadia Lake water level elevations between 1985 and 1995, before implementation of aquatic plant establishment efforts 
Water levels are important to aquatic plants for several reasons (Smart et al. 1996). Deep water during the critical dormancy-breaking period (Spring) for aquatic plants may reduce light to inhibit successful sprouting and survival of species planted too deeply relative to conservation pool. Longer periods of high water may deprive sprouted plants of light (and oxygen, in some emergent species), resulting in mortality. On the other hand, low-water conditions may expose plants to desiccation. While most species of aquatic plants exploit biological strategies (such as production of desiccation-resistant seeds and tubers) to overcome low-water conditions, newly establishing plants are highly susceptible and may not be able to recover from these events. Low-water conditions are most likely to impact submersed species, but because these are

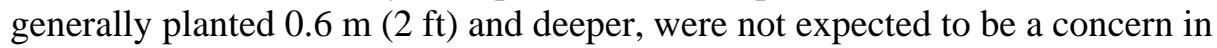
this project.

Common carp (Cyprinus carpio) were known to be abundant in the lake, and semiaquatic turtles had been observed (Gilliland 1996, pers. comm.). Both of these animals are opportunistic omnivores, readily make use of aquatic plants as a food source, and have been detrimental in other aquatic plant establishment projects (Doyle and Smart 1993; Dick et al. 1995; Smart et al. 1996). Other animals reported from the lake, including crayfish and beavers, also cause damage to newly installed aquatic plants in restoration projects. It was therefore decided that protective exclosures would be used to protect newly installed plants. At the same time, the design of exclosures would allow spread of aquatic plants to other areas.

Other obstacles expected to potentially limit plant establishment included turbidity and excessive wave action. Arcadia Lake exhibits high turbidities from time to time, particularly following heavy rains and during high-wind events, when waves stir up bottom sediments along shallow flats. At these times, Secchi disk readings of less than $20 \mathrm{~cm}$ (8 in.) are common, especially in shallow waters. High turbidity reduces light penetration, potentially narrowing the range of depths at which plants can successfully become established.

In addition to sediment resuspension and subsequent increases in turbidities, wave action produced by accompanying strong winds common to central Oklahoma can shift sediments in ways that may be detrimental to newly establishing plant colonies. Sediments can be scoured out, revealing root systems not yet developed and resulting in plants being washed away. Alternatively, sediments can be deposited at rates high enough to smother plants. To accommodate these possibilities, plants were installed at relatively shallow depths (1 m (3 ft) and less) in areas that were protected from wind and wave action (generally the backs of coves). 


\section{Methodology}

\section{Site Selection}

The lake was visited and potential planting sites were identified during summer 1995. Fifteen (15) sites were selected based upon two major criteria: (a) protection from wind and wave action, and (b) substrate texture (Figure 3). Protection from wind and wave action was generally found in the backs of coves, regardless of predominant wind direction. Waters associated with coves tended to be less turbid, affording greater light penetration and, therefore, greater potential survival of submersed plants. Additionally, reduced wave action lessened the probability of newly planted propagules being washed out or being covered by shifting sediments.

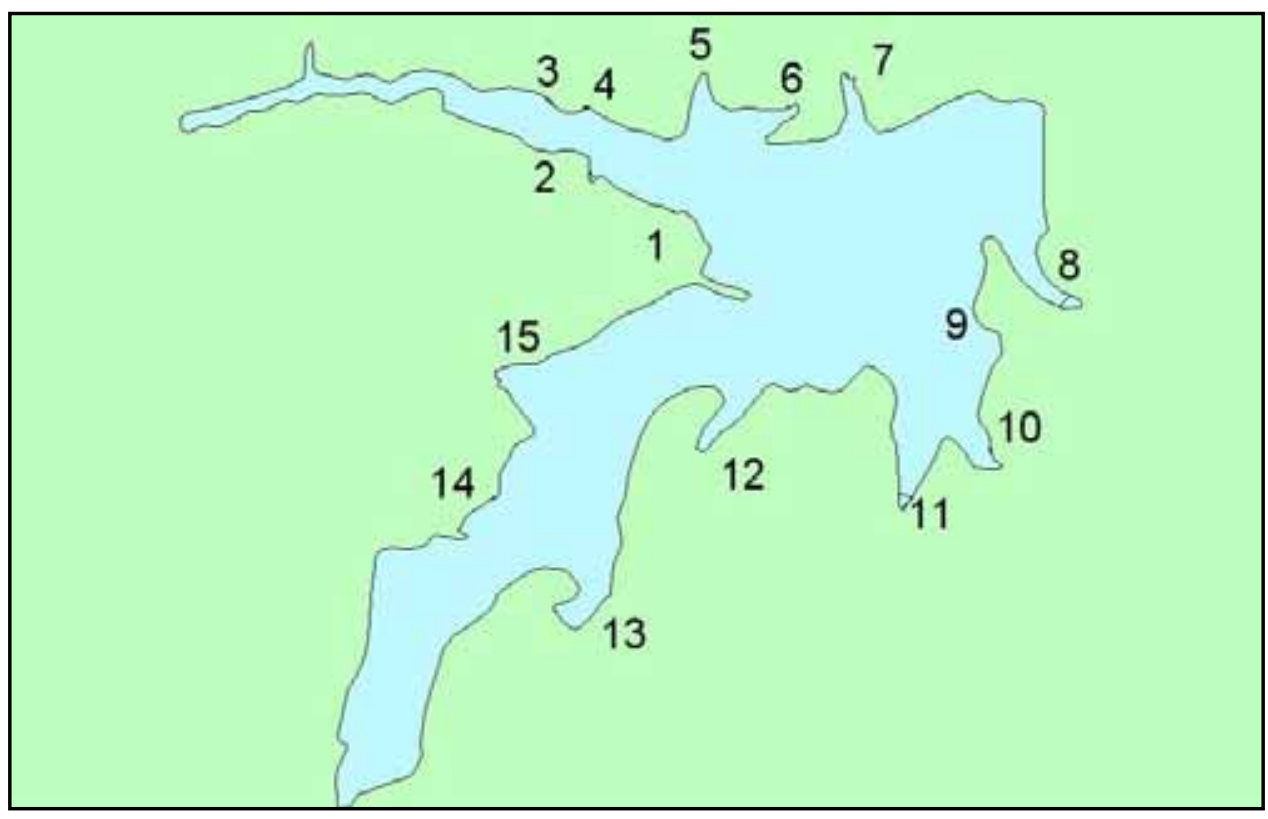

Figure 3. Fifteen sites were selected for aquatic plant founder colony establishment in Arcadia Lake

Soft bottoms were chosen to enable rooting by vegetation. Substrates selected ranged from sandy to muddy. Substrates of these types were generally found in the backs of coves, further supporting cove selection as project sites. 


\section{Plant Selection and Installation}

Aquatic plant species selection was based upon several criteria: (a) all species selected were native to Oklahoma; (b) no species selected were considered noxious under most conditions; and (c) all species exhibited potential to tolerate water level fluctuations and other conditions particular to Arcadia Lake. Native plant species, as opposed to introduced or exotic species, were selected because they provide suitable habitat for fish and other wildlife and, typically do not become problematic because of weedy overgrowth. Because potentially harsh and variable environmental conditions were anticipated, a diversity of native plants was selected for testing in 1997 to identify those best suited for establishment. This permitted second-year planting focus on those species most suitable for Arcadia Lake. Species (or propagule types) that exhibited poor success in 1997 were generally not replanted in 1998, although because of plant culture advances at Lewisville Aquatic Ecosystem Research Facility (LAERF), several species not tested in 1997 were included in 1998 planting.

Twenty-two (22) aquatic plant species were planted during 1997 and 1998 (Table 1). These species represented three growth forms, including submersed, floating-leaved, and emergent. As a rule, submersed forms have leaves and stems found beneath or at the water surface and commonly colonize $0.3 \mathrm{~m}(1 \mathrm{ft})$ and deeper water up to about $3 \mathrm{~m}$ ( $9 \mathrm{ft}$ ). Floating-leaved forms typically do not have permanent subsurface leaves, and usually occur in 0.6- to 2-m- (2- to 6.5-ft-) deep water. Emergent forms generally produce stems and leaves that are above

\begin{tabular}{|c|c|c|c|c|}
\hline \multicolumn{5}{|c|}{$\begin{array}{l}\text { Table } 1 \\
\text { Twenty-Two Native Aquatic Plant Species Were Planted in Arcadia Lake in } 1997 \text { and } 1998 \\
\text { (Several ecotypes or propagule types were tested for some species) }\end{array}$} \\
\hline Common Name & Species Name & Growth Form & Propagule & Year Planted \\
\hline Wild celery (3 ecotypes) & Vallisneria americana & Submersed & 4-in. pot \& tuber & 1997 and 1998 \\
\hline Sago pondweed & Potamogeton pectinatus & Submersed & Tuber & 1997 \\
\hline American pondweed & P. nodosus & Submersed & 4-in. pot \& tuber & 1997 and 1998 \\
\hline Illinois pondweed & P. illinoensis & Submersed & 4-in. pot & 1998 \\
\hline Water stargrass & Heteranthera dubia & Submersed & 4-in. pot & 1997 and 1998 \\
\hline Elodea & Elodea canadensis & Submersed & 4-in. pot & 1997 and 1998 \\
\hline Coontail & Ceratophyllum demersum & Submersed & Sprig & 1997 \\
\hline Spatterdock & Nuphar luteum & Floating-leaved & 6-in. pot & 1997 and 1998 \\
\hline White water lily & Nymphaea odorata & Floating-leaved & 6-in. pot & 1997 and 1998 \\
\hline American lotus & Nelumbo lutea & Floating-leaved & 4-in. pot \& apical tip & 1997 and 1998 \\
\hline Arrowhead & Sagittaria latifolia & Emergent & 4-in. pot & 1997 and 1998 \\
\hline Bulltongue & S. graminea & Emergent & 4-in. pot & 1997 and 1998 \\
\hline Pickerelweed & Pontederia cordata & Emergent & 6-in. pot & 1998 and 1998 \\
\hline Water willow & Justicia americana & Emergent & 6-in. pot & 1997 and 1998 \\
\hline Flatstem spikerush & Eleocharis macrostachya & Emergent & 4-in. pot & 1997 and 1998 \\
\hline Squarestem spikerush & E. quadrangulata & Emergent & 4-in. pot & 1997 and 1998 \\
\hline Slender spikerush & E. acicularis & Emergent & 4-in. pot & 1998 \\
\hline Softstem bulrush & Scirpus validus & Emergent & 6-in. pot & 1997 and 1998 \\
\hline Tall burhead & Echinodorus berteroi & Emergent & 4-in. pot & 1997 and 1998 \\
\hline Lizard's tail & Saururus cernuus & Emergent & 4-in. pot & 1998 \\
\hline Water hyssop & Bacopa monnieri & Emergent & 4-in. pot & 1998 \\
\hline Water pepper & Polygonum hydropiperoides & Emergent & 4-in. pot & 1998 \\
\hline
\end{tabular}


the water surface and are more often than not found in water less than $0.6 \mathrm{~m}(2 \mathrm{ft})$ deep, as well as moist soils. Planting depths for the three growth forms were: submersed species -0.6 to $1.2 \mathrm{~m}$ ( 2 to $4 \mathrm{ft}$ ) deep; floating-leaved species $-0.6 \mathrm{~m}$ ( $2 \mathrm{ft}$ ) deep; and emergent species -0 to $0.3 \mathrm{~m}$ (0 to $1 \mathrm{ft}$ ) deep.

Planting was initiated during the summer of 1997 and was completed during the summer of 1998. Initial plantings of each selected species were designed to ascertain the suitability of habitat and effectiveness of protective exclosures (of different types) for that species. Approximately 500 potted plants grown in 4- to 6-in. (nominal size) nursery-grade pots at the LAERF were initially planted during early summer, 1997. In addition to plants listed in Table 1, seeds and spores of southern naiad (Najas guadalupensis) and muskgrass (Chara vulgaris), both submersed forms native to Oklahoma, were introduced incidentally in substrates of potted plants. For some species, different propagule types (based upon commercial or otherwise availability) were planted to ascertain the most effective means of establishment of that species. In one case (wild celery), three locality types, including Texas, Tennessee, and Wisconsin, were tested. In all, approximately 1,400 plants were installed in Arcadia during the course of this project.

\section{Exclosure Construction and Planting Designs}

Establishment of aquatic plants in unvegetated reservoirs requires protection from herbivores (Dick et al. 1995; Smart et al. 1996; Doyle et al. 1997). Newly installed plants are less tolerant of environmental stresses than well-established plants, and may perish if subjected to excessive disturbances such as herbivory. Because Arcadia supported several species of omnivores, most notably common carp and semiaquatic turtles, protection of newly installed plants was anticipated. Various forms of protection were constructed at each site during the spring of 1997, including large-scale and small-scale exclosures (Figure 4). Modifications of some exclosures and additional exclosures were constructed during 1998, following results of plantings made in 1997, which identified specific exclosure requirements to protect against Arcadia Lake herbivores. Large-scale exclosures were designed to protect multiple numbers and species at various depths. Smallscale exclosures were designed to protect individual or small groups of a single species at specific depths. The trade-off between the two types was establishment over a large area versus a higher level of protection: small cages are the least likely to be breached. Mesh size of $5 \times 10 \mathrm{~cm}(2 \times 4 \mathrm{in}$.) (nominal) had proven adequate to exclude common carp and turtles in other restoration projects and was used in this project. A smaller mesh size, 3.8-cm- (1.5-in.-) (nominal) diamond mesh, was also used to test any need for finer exclusion.

\section{Large-scale exclosures}

Large-scale exclosures included three types: pens, cove fences, and shoreline fences. Pens measured $5 \mathrm{~m}$ wide $\times 10 \mathrm{~m}$ long $\times 1.4 \mathrm{~m}$ high $(15 \mathrm{ft}$ wide $\times$ $30 \mathrm{ft}$ long $\times 4.5 \mathrm{ft}$ high) and were positioned parallel to one another at a distance of 10 to $15 \mathrm{~m}$ (30 to $45 \mathrm{ft}$ ). This positioning allowed future tie-ins to produce a 


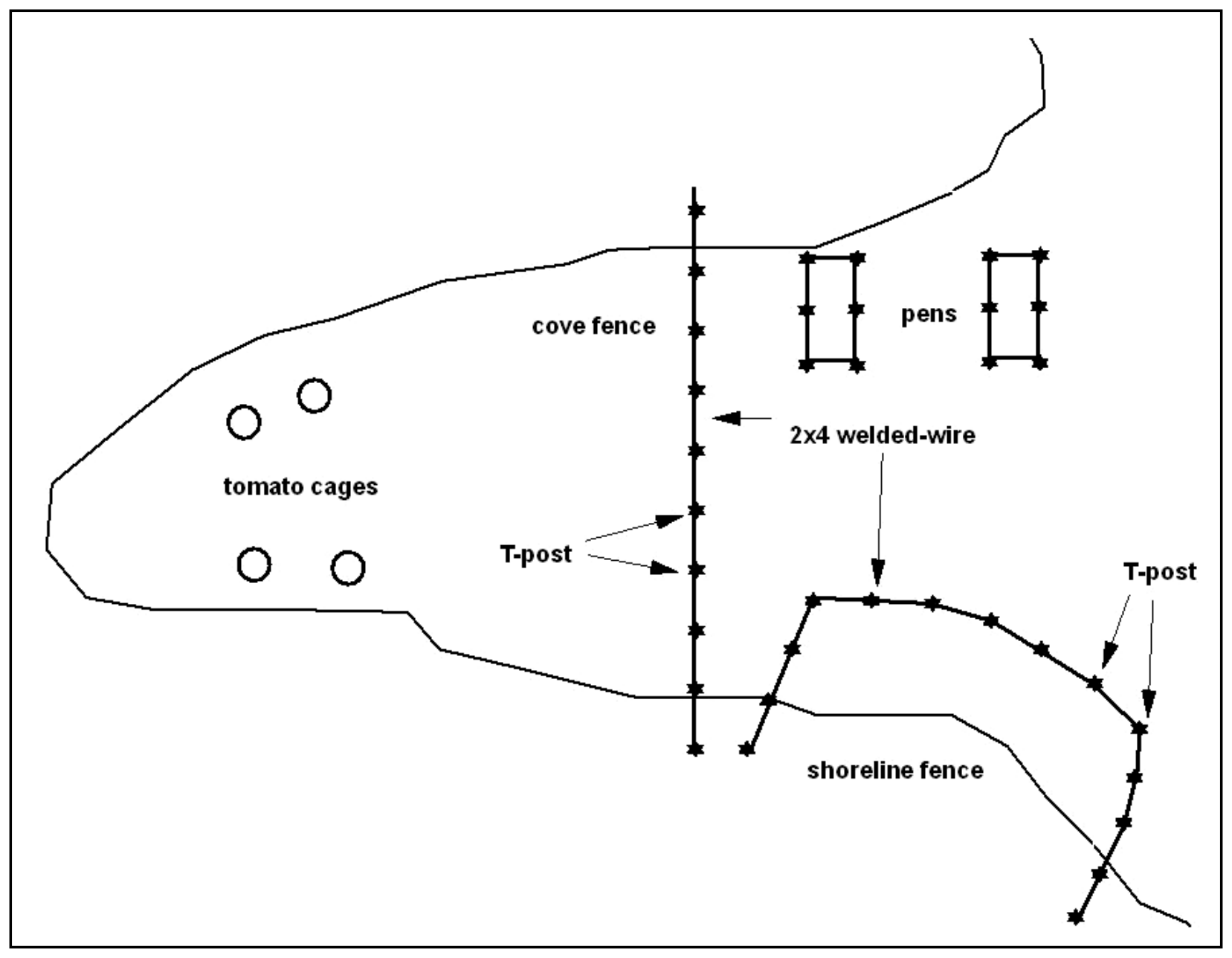

Figure 4. Various large- and small-scale protective exclosures were constructed in Arcadia Lake to reduce herbivore pressure on aquatic plants

single large, compartmented exclosure measuring $10 \mathrm{~m} \times 20+\mathrm{m}(30 \mathrm{ft} \times 60+\mathrm{ft})$. The frame of each pen consisted of t-posts set to a depth of 0.5-m- (1.5-ft-) and covered with 1-5/8-in. (nominal) galvanized fence posts. Galvanized top rails were installed to firm up the frame, and 5- $\times 10-\mathrm{cm}-(2-\times 4$-in.-) mesh, galvanized welded-wire was attached using aluminum wire ties. A $0.5-\mathrm{m}-(1.5-\mathrm{ft}-)$ wide bottom flange was built into the fencing to discourage digging underneath. Pens were constructed in 0.5- to $1.1-\mathrm{m}$ (1.5- to 3.5-ft) depths at conservation pool, leaving a minimum of $0.3 \mathrm{~m}(1 \mathrm{ft})$ of protective caging above the waterline at conservation pool. Pens were designed for protecting relatively large colonies of submersed plants species. Each pen was originally planted with 24 potted plants. Generally, two species were planted per pen, with one-half of the pen planted with each species. Species initially planted in pens included American pondweed, sago pondweed, elodea, and water stargrass.

Cove fences consisted of 1-5/8-in. galvanized fence posts (set over t-posts) and galvanized top rail and were constructed to an elevation at least $0.5 \mathrm{~m}(1.5 \mathrm{ft}$ ) above conservation pool and stretched across the cove mouth, blocking access into the cove by waterborne herbivores. Mesh galvanized welded-wire, 
$(5 \times 10 \mathrm{~cm}(2 \times 4 \mathrm{in}$.)) was attached to this frame. Cove fences were designed to protect submersed, floating-leaved, and emergent plant species from waterborne herbivores (terrestrial grazers were not excluded). In most cases, these plants were additionally protected by small-scale exclosures, although some plants were planted without additional protection to test the effectiveness of the cove fence.

Shoreline fences were constructed from t-posts and 5- $\times 10$-cm- (2- $\times 4$-in.-) mesh, galvanized welded-wire. Each shoreline fence extended from about $0.5 \mathrm{~m}$ $(1.5 \mathrm{ft})$ above the conservation pool shoreline to a depth of about $1 \mathrm{~m}(3 \mathrm{ft})$, and ran about $20 \mathrm{~m}(60 \mathrm{ft})$ along the shoreline, typically protecting an area of $200 \mathrm{~m}^{2}$ $\left(2,150 \mathrm{ft}^{2}\right)$. Fence materials were not installed on the shoreward side of these fences, which were either freestanding or built as additions to cove fences. This type of fence was designed to protect plants from waterborne herbivores and did not exclude terrestrial grazers. Shoreline fences were designed to protect submersed, floating-leaved, and emergent species. Large-scale exclosures and modifications constructed at the 15 sites during 1997 and 1998 are given in Table 2.

\begin{tabular}{l}
\hline $\begin{array}{l}\text { Table } \mathbf{2} \\
\text { Large-Scale Protective Exclosures }\end{array}$ \\
Modified at Most of the 15 Sites in Arcadia Lake during 1997 and \\
$\mathbf{1 9 9 8}$
\end{tabular}

\section{Small-scale exclosures}

Small-scale exclosures included two general types: tomato cages and orange cages. These cages were installed either inside or outside of large-scale exclosures. Installation inside provided additional protection in the event of breaches in the larger exclosure. Table 3 provides numbers of each cage type installed at each site. 
Tomato cages were constructed from 5- $\times 10$-cm- (2- $\times$ 4-in.-) mesh galvanized welded-wire at heights of 1 to $1.2 \mathrm{~m}$ (3 to $4 \mathrm{ft}$ ), dependent upon planting depth and species (Figure 5). A 2-m (6-ft) length of welded-wire was formed into an open-ended cylinder approximately $0.6 \mathrm{~m}(2 \mathrm{ft})$ in diameter and anchored with pieces of rebar to protect individual plants. A larger version of the tomato cage was constructed in similar fashion, but greater lengths of weldedwire were used to form cylinders ranging from 1 to $2 \mathrm{~m}$ ( 3 to $6.5 \mathrm{ft}$ ) in diameter (herein referred to as ring cages). Single plants of all species tested were planted in tomato cages. An additional plant of the same species was planted outside some tomato cages (whether or not additionally protected by large-scale exclosures) to evaluate the effectiveness of herbivore protection by the cages.

\begin{tabular}{|c|c|c|c|}
\hline \multicolumn{4}{|c|}{$\begin{array}{l}\text { Table } 3 \\
\text { Arcadia Lake Restoration Sites and } \\
\text { Small-Scale Protective Exclosures } \\
\text { Constructed at Each }\end{array}$} \\
\hline \multirow[b]{2}{*}{ Site } & \multicolumn{2}{|c|}{ Tomato or Ring Cages } & \multirow{2}{*}{\begin{tabular}{|c|}
$\begin{array}{c}\text { Orange } \\
\text { Cages }\end{array}$ \\
1997 \\
\end{tabular}} \\
\hline & 1997 & 1998 & \\
\hline 1 & 18 & 18 & 0 \\
\hline 2 & 66 & 24 & 18 \\
\hline 3 & 12 & 12 & 0 \\
\hline 4 & 6 & 4 & 0 \\
\hline 5 & 12 & 12 & 0 \\
\hline 6 & 12 & 40 & 0 \\
\hline 7 & 12 & 6 & 0 \\
\hline 8 & 40 & 6 & 12 \\
\hline 9 & 12 & 18 & 0 \\
\hline 10 & 24 & 12 & 8 \\
\hline 11 & 114 & --- & 12 \\
\hline 12 & 12 & --- & 0 \\
\hline 13 & 32 & 3 & 0 \\
\hline 14 & 32 & --- & 0 \\
\hline 15 & 12 & 6 & 0 \\
\hline Total & 416 & 161 & 42 \\
\hline
\end{tabular}

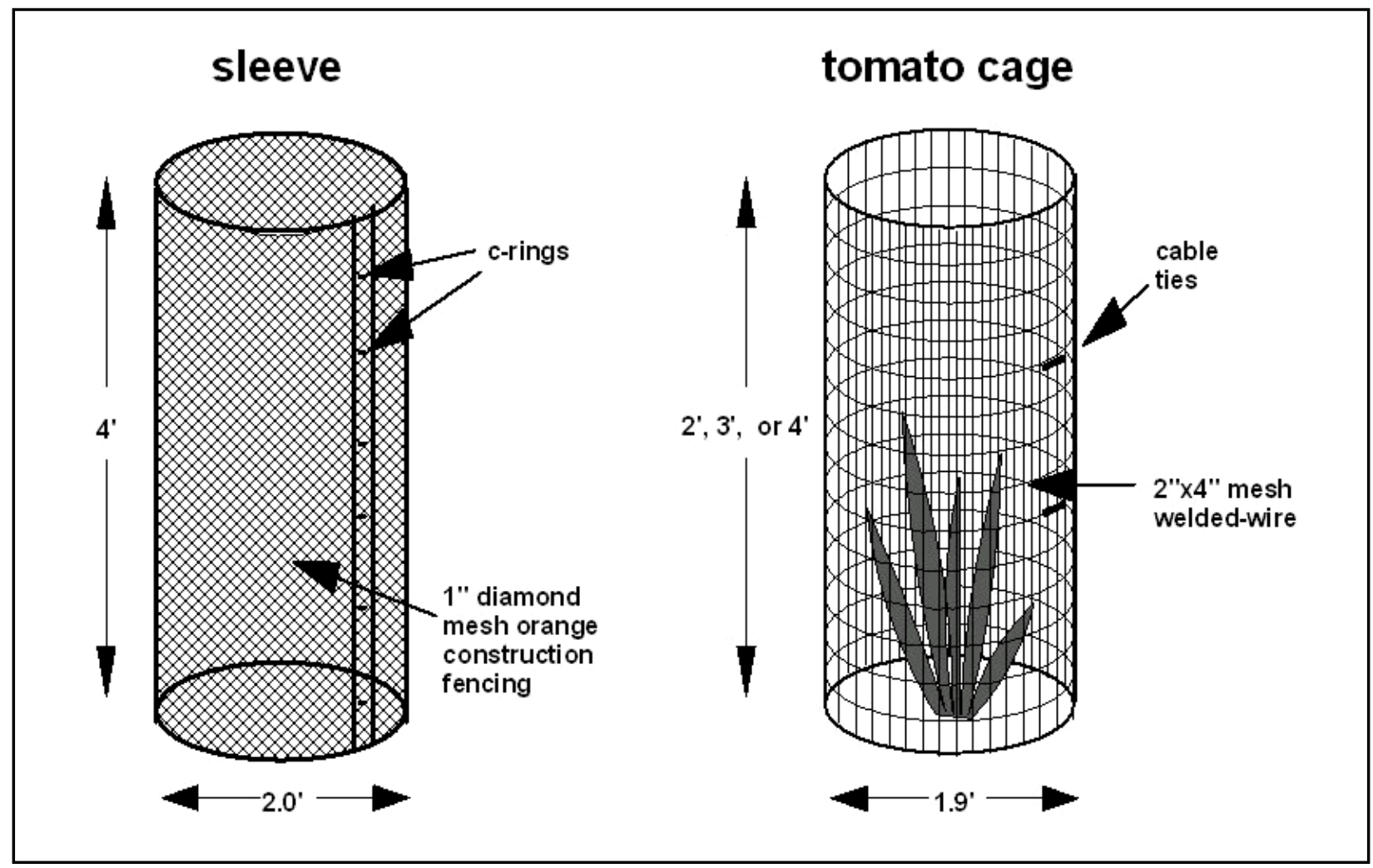

Figure 5. Tomato cages served as small-scale protection for individual plants in Arcadia Lake. In some cases, sleeves constructed from plastic fencing were installed over wire-mesh cages (To convert feet to meters, multiply by 0.305 ; to convert inches to centimeters, multiply by 2.54 ) 
Orange cages were constructed from orange plastic construction fencing (3.8-cm (1.5-in.) diamond mesh) and rebar and stiffened with PVC piping (Figure 6). Each plastic fence measures $1.8 \mathrm{~m}$ wide $\times 1.8 \mathrm{~m}$ long $\times 1.2 \mathrm{~m}$ high ( $6 \mathrm{ft}$ wide $\times 6 \mathrm{ft}$ long $\times 4 \mathrm{ft} \mathrm{high).} \mathrm{Small} \mathrm{groups} \mathrm{(four} \mathrm{individuals)} \mathrm{of} \mathrm{either}$ American pondweed or elodea were originally planted in each orange cage.

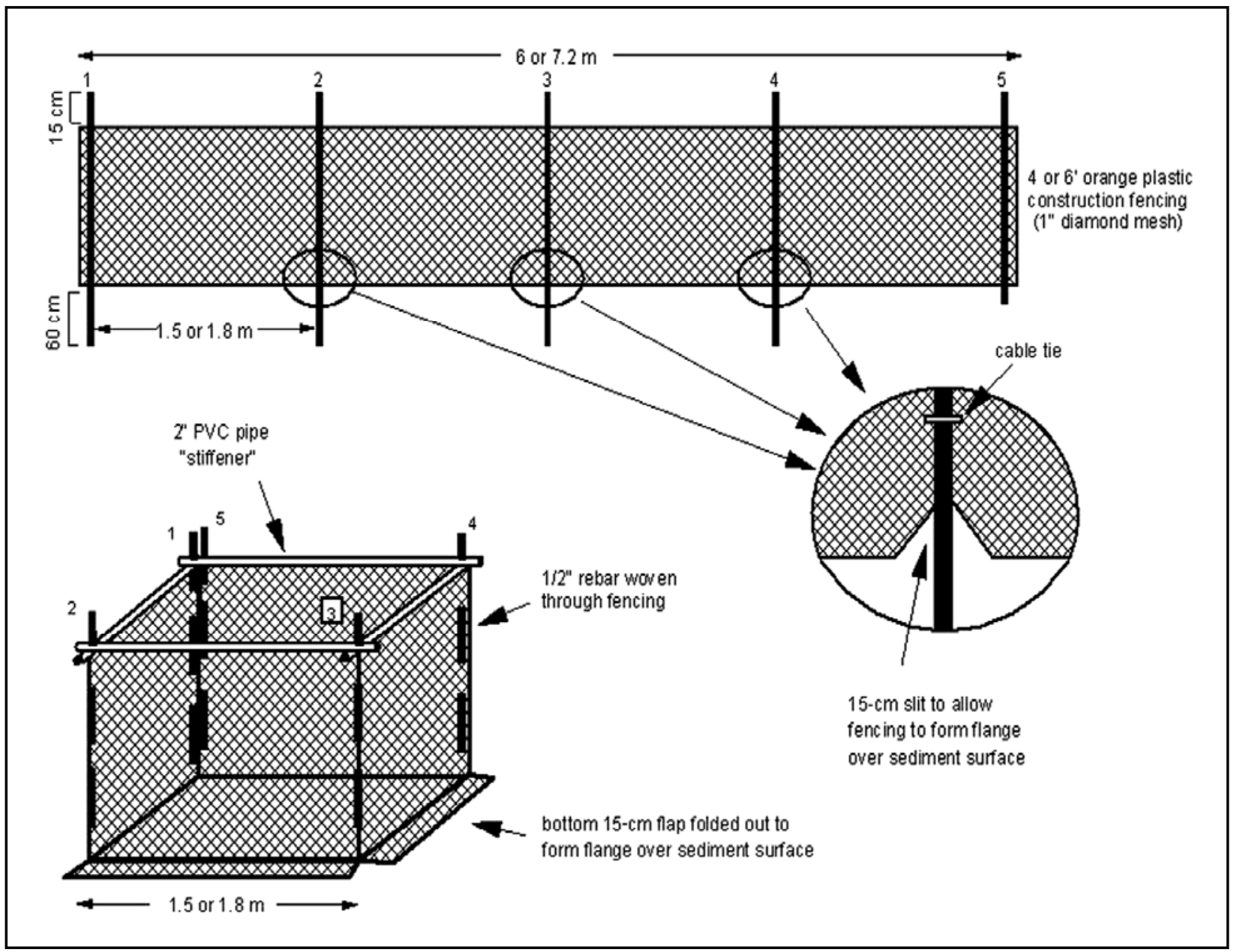

Figure 6. Orange cages served as small-scale protection for small sets of plants in Arcadia Lake (To convert feet to meters, multiply by 0.305 ; to convert inches to centimeters, multiply by 2.54 )

\section{Assessments and Additional Planting}

Assessments of plantings were conducted periodically throughout the growing seasons of 1997 and 1998, and data in this report include that collected in July and September 1997, June and October 1998, and June 1999. A follow-up assessment at some sites was made during 2001 to ascertain long-term success of the project (Appendix A). Survival, growth, and spread of each species were monitored during these assessments, with focus on individual plants during 1997 and colonies of plants in 1998 through 2001. Plants newly tested during 1998 were also monitored at the individual level during that year. Survival was recorded for a plant when living stems and leaves remained present; however, many plants that suffer damage to aboveground portions are capable of 
recovering from underground propagules. This may have led to higher estimates of mortality than had actually occurred. Additionally, leaves and stems of plants are not always easily visible underwater, and some plants may have been present but not seen. Growth was measured by comparing area coverage of each plant or colony over time. In 1997 and 1998, area was calculated by averaging measurements of length and width (Figure 7). The occurrence of spread from protective exclosures was recorded for each species at all assessments, and evidence of grazing or other damage was recorded.

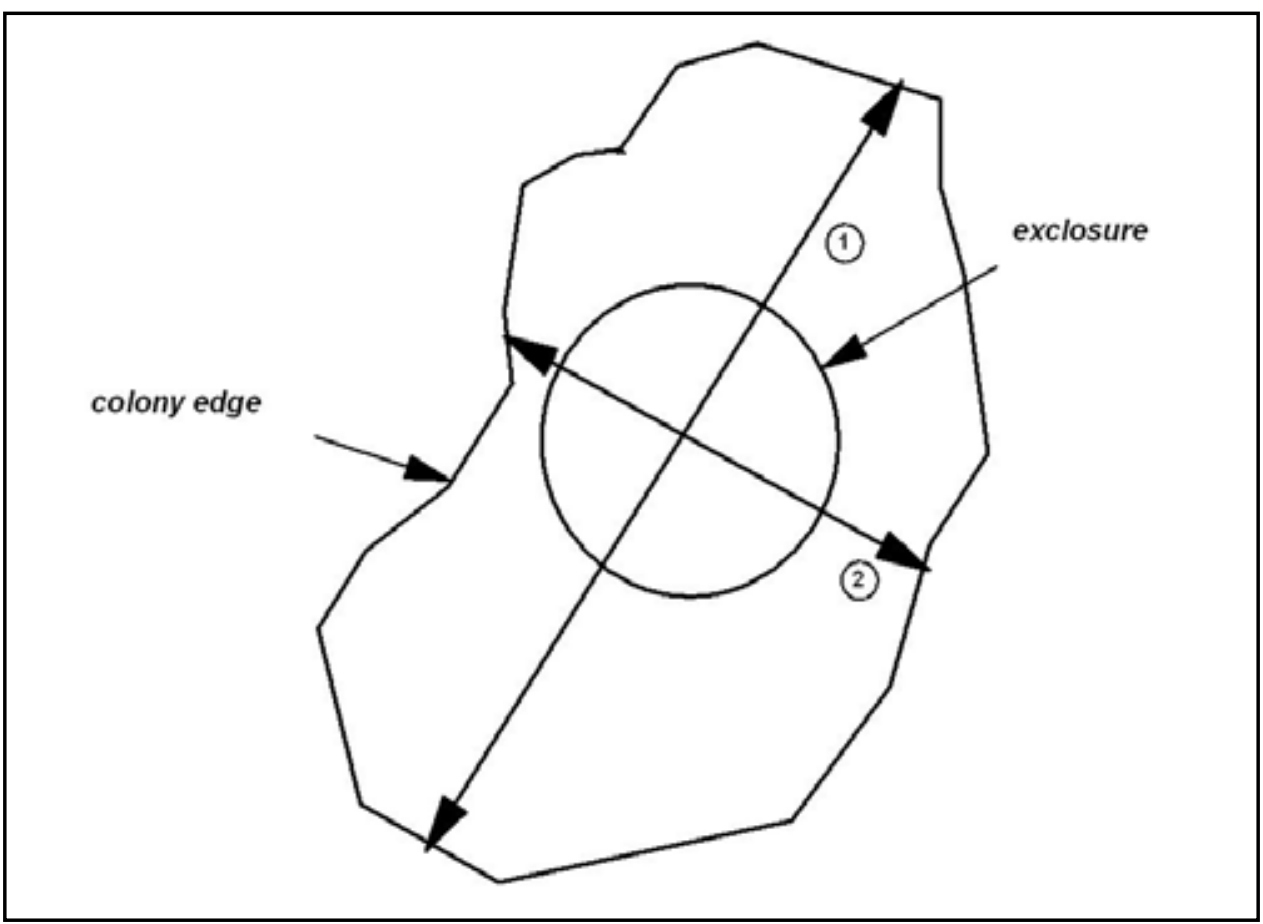

Figure 7. Plant and colony size estimates were made by (a) measuring colony length, (b) measuring colony width, (c) averaging length and width, and (d) recording as diameter

During 1999 and 2001, plant colony locations were measured by Global Positioning System (GPS) mapping, and Geographical Information System (GIS) maps constructed from these data. Multiple points were recorded using a Trimble Asset surveyor TSC1 backpack unit with real-time correction activated (RTC link). GIS data analysis was conducted in ArcView, and areas were calculated from a Universal Transverse Mercator 1983 (UTM 83) projection.

Condition of exclosures was examined during each assessment visit, and repairs were made when necessary. During 1997 and 1998 assessments, replacement planting was undertaken in cases where plants had not survived. During 1997, the same species was replanted, except in the case of American lotus; in 1998, those species that had exhibited the greatest survivorship at a given site (or in the lake as a whole) were used to replant empty cages, regardless the original species planted. 


\section{Results}

\section{Water Levels}

For the most part, water levels fluctuated as anticipated during this project, with short-lived, periodic high-water conditions occurring during the growing season (Figure 8). The high-water conditions may have contributed to common carp and turtles breaching large-scale exclosures, as water topped portions of all of these structures on at least one occasion.

Unusually low-water conditions occurring near the end of the 1998 summer potentially impaired establishment of some plant species, particularly submersed forms such as wild celery and Illinois pondweed, which have a lower desiccation tolerance than do other species. At the same time, low water may have benefited some species with higher desiccation tolerance (primarily emergent forms) by reducing the likelihood of aquatic herbivory.

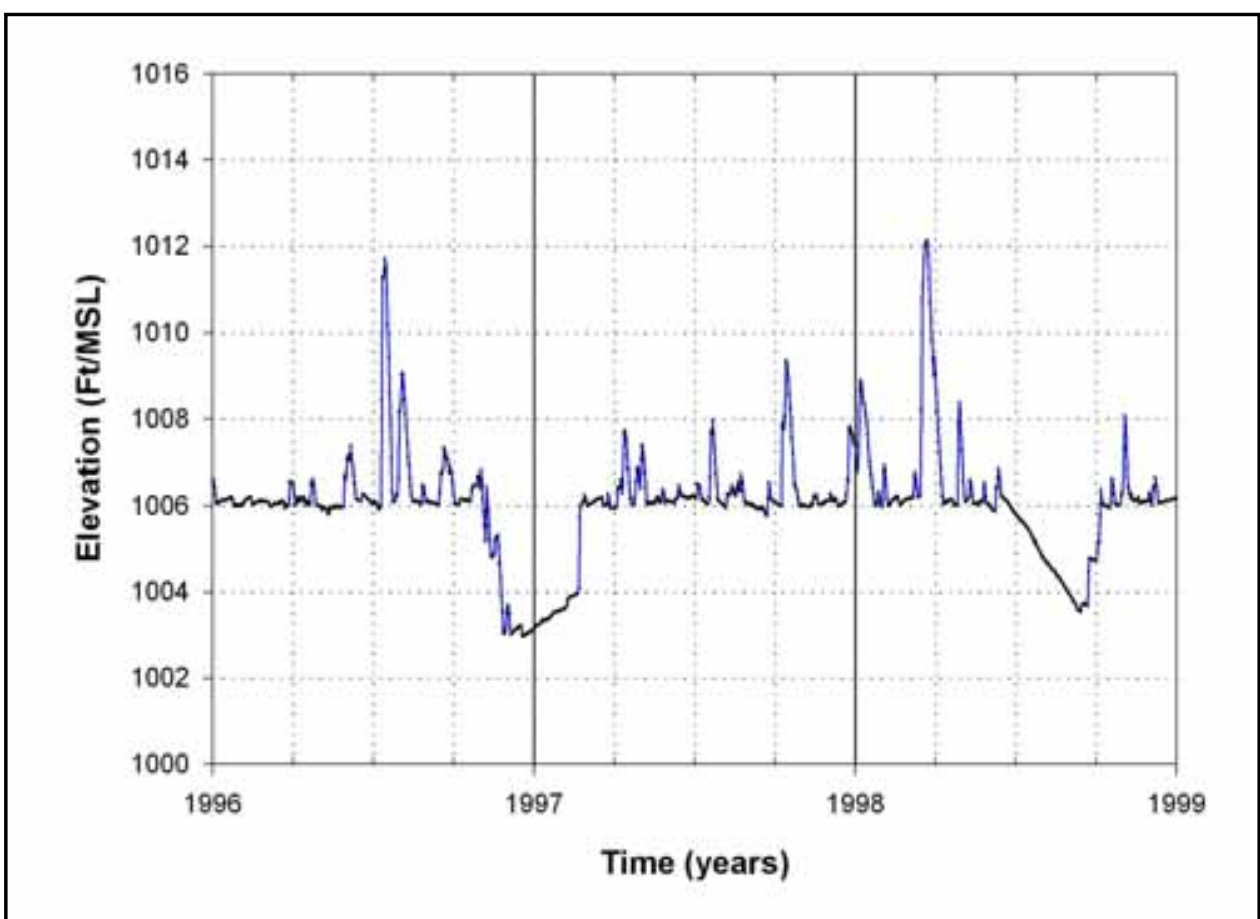

Figure 8. Arcadia Lake water levels fluctuated significantly from conservation pool (307 m msl (1,006 ft msl)) during 1997 and 1998 


\section{Assessments}

By July 1997, individuals of all species (except Wisconsin wild celery planted from tubers) planted in June had survived transplanting and were growing inside protected areas. Cages that did not support plants were replanted with the same species during the July assessment. Table 4 provides survival percentages of protected and unprotected plants installed in tomato cages, orange cages, pens, and without protection. Most individuals (78 percent) planted in tomato cages had survived 8 weeks after planting (July), but survival had declined to 60 percent by September, despite empty cages being replanted in July. Loss of submersed and floating-leaved species contributed greatest to this decline, and two factors were identified as most likely causes: (a) fluctuating water levels and (b) herbivory.

\begin{tabular}{|c|c|c|c|c|c|c|}
\hline \multicolumn{7}{|c|}{$\begin{array}{l}\text { Table } 4 \\
\text { Percent Survival of Aquatic Plants Species and Ecotypes Protected } \\
\text { by Small-scale Exclosures and Not Protected by Small-Scale } \\
\text { Exclosures During } 1997 \text { (Plants were installed in early June 1997, } \\
\text { and empty cages were replanted in July 1997) }\end{array}$} \\
\hline \multirow[b]{3}{*}{ Species } & \multicolumn{6}{|c|}{$\%$ Survival } \\
\hline & \multicolumn{3}{|c|}{30 July 1997} & \multicolumn{3}{|c|}{24 Sep 1997} \\
\hline & \begin{tabular}{|l|}
$\begin{array}{l}\text { Tomato } \\
\text { Cage }\end{array}$ \\
\end{tabular} & No Cage & \begin{tabular}{|l|}
$\begin{array}{l}\text { Orange } \\
\text { Cage }\end{array}$ \\
\end{tabular} & \begin{tabular}{|l|}
$\begin{array}{l}\text { Tomato } \\
\text { Cage }\end{array}$ \\
\end{tabular} & No Cage & \begin{tabular}{|l}
$\begin{array}{l}\text { Orange } \\
\text { Cage }\end{array}$ \\
\end{tabular} \\
\hline American pondweed potted & 65 & 16 & 77 & 54 & 0 & 48 \\
\hline American pondweed tuber & 33 & 0 & & 0 & 0 & \\
\hline Sago pondweed & 42 & 0 & & 0 & 0 & \\
\hline Water stargrass & 72 & 9 & & 67 & 0 & \\
\hline Wild celery (TX) plant & 100 & 0 & & 50 & 0 & \\
\hline Wild celery (TN) plant & 75 & 0 & & 33 & 0 & \\
\hline Wild celery (WI) tuber & 0 & 0 & & 0 & 0 & \\
\hline Elodea & 55 & 0 & 25 & 0 & 0 & 25 \\
\hline Coontail & 100 & --- & & 17 & --- & \\
\hline American lotus & 6 & 0 & & 31 & 0 & \\
\hline Spatterdock & 83 & 0 & & 33 & 0 & \\
\hline White water lily & 96 & 0 & & 78 & 0 & \\
\hline Softstem bulrush & 100 & 100 & & 100 & 67 & \\
\hline Squarestem spikerush & 100 & 33 & & 100 & 33 & \\
\hline Flatstem spikerush & 100 & 83 & & 100 & 83 & \\
\hline Water willow & 100 & 67 & & 100 & 67 & \\
\hline Arrowhead & 86 & 16 & & 57 & 16 & \\
\hline Bulltongue & 100 & 16 & & 100 & 16 & \\
\hline Tall burhead & 100 & 0 & & 100 & 16 & \\
\hline Pickerelweed & 96 & 16 & & 71 & 16 & \\
\hline Mean & 78 & 20 & 51 & 60 & 16 & 36 \\
\hline
\end{tabular}

Arcadia Lake is subject to rapid fluctuations, particularly following rain events, and a significant rise in water level (by $1 \mathrm{~m}$ or more) in a short period (within 1 day) is common. For flood control, excess water is released over a period of several days. When water levels rise, submersed and floating-leaved 
species stems elongate until they reach the water surface (Figure 9). Elongated stems were apparently prone to becoming entangled in cage mesh and were trapped above water when water levels declined, exposing much of the biomass of each establishing plant to desiccation. In some cases, damage was evidently sufficient to cause mortality of the plant. Rapid rise in water levels occurred once after initial planting in June, and again after replanting in July, possibly accounting for much of the mortality not attributable to other causes, at least in the cases of submersed and floating-leaved species.

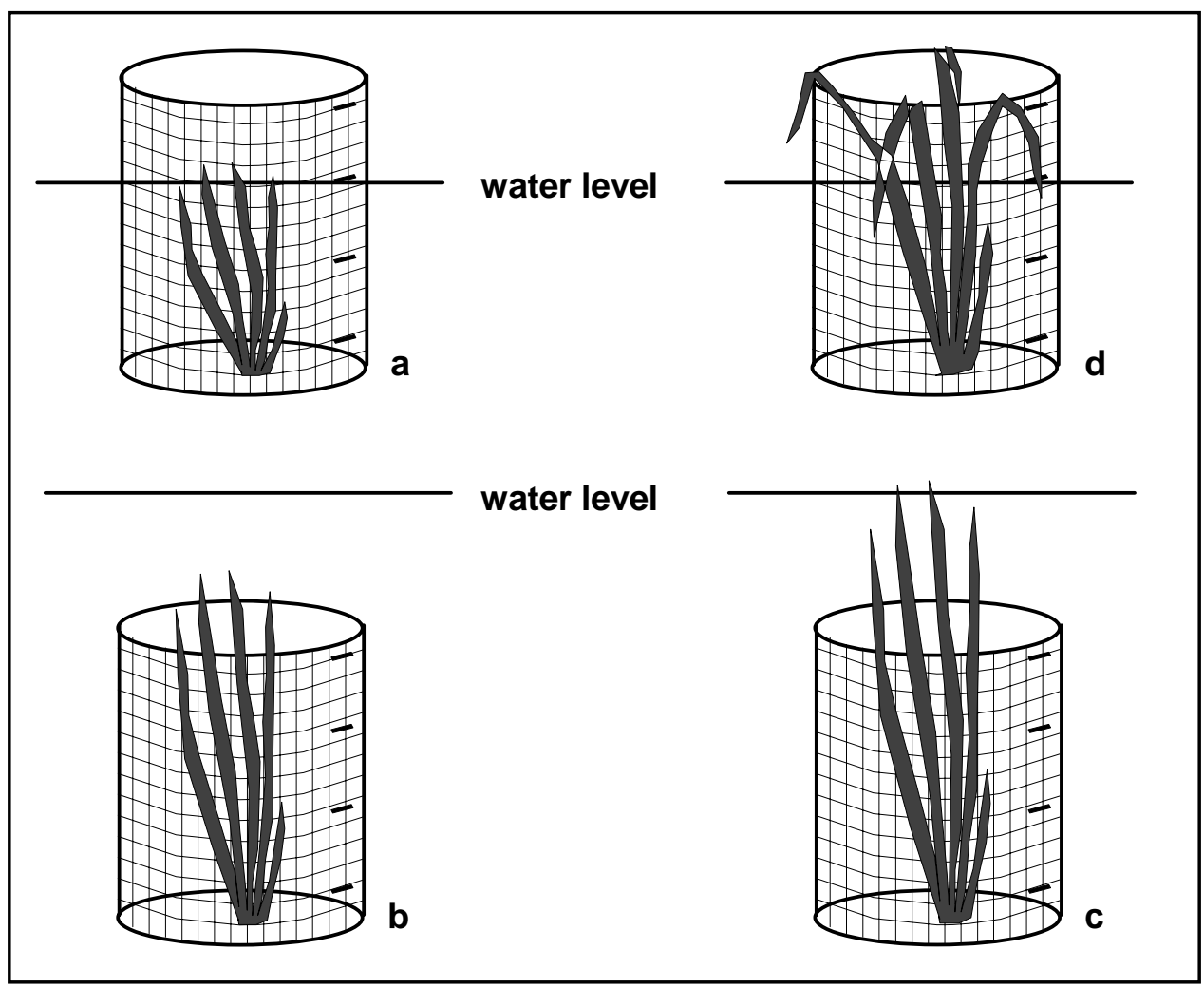

Figure 9. Fluctuating water levels apparently affected submersed and floatingleaved plant survival in tomato cages: a) at normal pool, plants grew to reach the surface; but b) as water levels rose during a flood event, plant stems began to elongate; until c) reaching the surface, and following return to normal pools; and d) elongated stems were prone to becoming entangled in the mesh and over the tops of cages

Herbivores, including carp, turtles, and crayfish, although not evident during the July assessment, were found inside several cages in September. Carp and turtle populations in Arcadia Lake included small individuals capable of passing through 5- $\times 10-\mathrm{cm}(2-\times 4$-in.) mesh, and in many cases, grazing was evident on plants inside cages, particularly on submersed species. In some cases, cages had been dug under: no herbivores were found in these cages (except for one common carp), but plants were either missing or severely grazed. Survival in tomato cages did not appear to be affected by whether or not a cage was additionally protected by a cove fence, probably because mesh size between both exclosure types was the same. In other words, 5- × 10-cm (2- × 4-in.) mesh did not exclude all the carp and turtles, and both were able to gain entry into protected areas and 
feed on plants. Submersed species appeared to be the most susceptible to herbivore damage.

Submersed plants protected by orange cages exhibited survival (51 percent) similar to those planted in tomato cages (58 percent) by July. Although orange cages did not appear to ensnare stems as badly during high-water events, they were individually much more prone to breaches: something had burrowed under many of the orange cages by July, and all cages that did not support plants had been breached in this manner. However, many of the breached cages continued to support plants, even though these plants showed evidence of grazing.

Unbreached orange cages exhibited 100-percent survival, indicating that the finer mesh provided protection from some of the herbivores that were gaining entrance to tomato cages and digging beneath other orange cages.

Survival of plants not protected by small-scale exclosures was much lower (20 percent) than that of those protected with orange or tomato cages by July, indicating that herbivory was the dominant factor in establishment of vegetation in this lake. Additionally, plants that were surviving showed signs of herbivory and were generally smaller than plants inside cages. When plants were not additionally protected by a cove fence, survival did not occur. Cove fences, therefore, were providing a level of protection, possibly by reducing the density of herbivore populations: larger herbivores were excluded, although smaller individuals continued to enter exclosures through the mesh and graze on uncaged plants behind the fence. Although small enough to pass through the mesh, this may have been somewhat difficult (such as turtles having to turn sideways) and unprotected plants were more prone to grazing. Submersed and floating-leaved species were more susceptible to herbivory than emergent species, further implicating carp and turtles (which generally do not feed in shallow waters or shun some emergent species) as the most problematic herbivores in Arcadia Lake. By September, unprotected submersed or floating-leaved species were not observed, although survival of unprotected emergent species declined slightly. However, evidence suggested that beaver and terrestrial herbivores (deer and rabbits) were grazing on emergent species by that time.

In many cases, where survival had occurred, plants had grown to fill smallscale protective cages. However, spread beyond exclosures was limited during 1997 and occurred for only a few species. American pondweed, white water lily, softstem bulrush, and water willow had begun to grow outside of cages by September, but in most cases showed evidence of grazing.

Pens were planted with nine individuals of two of four submersed species, including American pondweed, water stargrass, sago pondweed, and elodea. Survival of these species is given in Table 5 . No breaches in the pens were observed, and herbivores were successfully excluded from plants during this growing season, despite the opportunity to invade pens during a high-water event in late summer. Submersed plants had grown to nearly fill the pens, but spread outside was minimal, apparently prevented by heavy grazing (by common carp and/or turtles). Submersed and floating-leaved plants installed inside cove fences had survived, but most showed signs of herbivory and were not as vigorous as nearby plants in tomato and orange cages. High-water conditions and small 


\begin{tabular}{|c|c|c|}
\hline \multicolumn{3}{|c|}{$\begin{array}{l}\text { Table } 5 \\
\text { Survival of Submersed Aquatic Plant } \\
\text { Species Protected by Pens during } 1997 \\
\text { (Plants were installed in early June } \\
1997 \text { ) }\end{array}$} \\
\hline Species & 30 July 1997 & 24 Sep 1997 \\
\hline American pondweed & 100 & 100 \\
\hline Sago pondweed & 5 & 0 \\
\hline Water stargrass & 83 & 50 \\
\hline Elodea $^{1}$ & 0 & 25 \\
\hline
\end{tabular}

breaches in the cove fences permitted entry of small numbers of common carp observed inside, resulting in poorer success of plants not additionally protected by smaller cages.

Three ecotypes (represented by two propagule types: Texas potted plants, Tennessee potted plants, and Wisconsin tubers) of wild celery and two propagule types of American pondweed (potted plants and tubers) were tested during 1997, with all types of both species planted in tomato cages at several sites.

Most Texas and Tennessee wild celery plants survived at the July survey but were in decline by September, apparently the result of herbivory. Wisconsin wild celery tubers either failed to sprout or did not survive herbivore pressure, indicating the northern ecotype was not suitable for Arcadia Lake. American pondweed potted plants exhibited higher survival and were more robust than those sprouted from tubers in July. By September, no tuber plants were surviving. These tests indicated that potted plants were more suitable for establishment in Arcadia Lake, and for the remainder of the project, additional plantings did not include tubers for these species.

Most species of aquatic plants tested in Arcadia Lake during 1997 survived and grew within protective exclosures, particularly those not breached by herbivores. Two species that did not apparently survive were excluded from additional planting in 1998, and included sago pondweed and coontail. Species not tested during 1997; but included in 1998 plantings, were Illinois pondweed, slender spikerush, water hyssop, lizard's tail, and water pepper.

\section{Assessments}

During 1998, plant establishment efforts and assessments were focused primarily on founder colony formation, including establishment and spread of colonies within protected areas (for eventual spread to unprotected areas within the lake). Additional plantings of species that had established in 1997 were undertaken, and protected areas in most sites were expanded and modified to improve herbivore exclusion. Postdormancy recovery, second-year survival, and spread of species planted in 1997 were also monitored during 1998.

The lake was visited in early June 1998. Some cages and pens had suffered damage during high spring waters, mostly from floating logs. Fenced coves had been breached by beavers during the winter, and common carp had entered the protected areas in large numbers. Efforts were made to repair the breaches and remove the carp from these areas (by "herding" them out through breaches). For the most part, these efforts were successful. Water levels had risen above some pens during the winter, and small numbers of carp were trapped inside several of 
these cages and pens after water levels returned to conservation pool. These carp were hand-removed.

Expansion and modifications of protected areas were made to increase founder colony sizes. Modifications to existing structures included joining pens and adding orange construction fencing to existing fences and pens to reduce mesh size. New construction included shoreline fences (Figure 4), in which fences were installed parallel to the shoreline and to a depth ranging from 1 to $1.2 \mathrm{~m}$ ( 3 to $4 \mathrm{ft}$ ), dependent upon the site. The backs of these fences were not enclosed, offering protection only from waterborne grazers. Orange cage breaches were repaired by additionally anchoring bottom flanges with pieces of rebar bent into "L" shapes. New tomato cages installed during 1998 were wrapped with orange construction fencing to exclude smaller herbivores.

Following repairs and new construction, more plants were installed at the sites to speed the process of establishing colonies. These species included those that had successfully established inside exclosures during 1997, as well as several that had not yet been tested.

In July 1998, water levels began to fall steadily, reaching 1,003 msl, or about

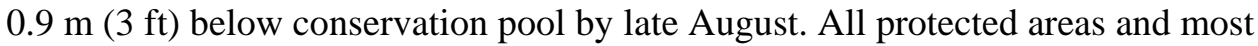
plants (with the exception of some deeper planted submersed species) were exposed to desiccation at that time. Rainfall in September brought the lake back to conservation pool, and many plants had recovered by the time of the final assessment. Several holes dug under fences by beaver were found along cove fences during the low-water period, but these were not repaired: fence locations and beaver preference to travel under some of them resulted in maintenance cessation of cove fences at some sites. Following return to conservation pool, small numbers of common carp were occasionally observed inside the fenced coves and removal techniques were engaged with limited success. A floating turtle trap set behind the cove fence in June yielded 42 red-eared sliders when checked after 2 weeks. At this time, maintenance of cove fences was abandoned and efforts were shifted to maintaining small-scale exclosures behind them.

Rather than survival of individual plants, 1998 assessments focused on survival of plant colonies. By the end of September 1998, over 340 colonies had been established at the 15 sites (Table 6). For the most part, each site included at least one species from each of the three growth forms (submersed, floatingleaved, and emergent). American pondweed was the best-established submersed species, white water lily, the best-established floating-leaved species, and softstem bulrush, the best established emergent species.

Potted plants (submersed) installed inside of the newly protected areas (areas between pens; shoreline fences; etc.) had established and spread within protected areas. Additionally, colonies of submersed plants inside pens (established in 1997) had spread into newly protected areas between them. Colonies declined during low-water levels, but by the end of the growing season, many of these areas were filled or nearly filled with plants. Spread to unprotected areas from these colonies was occasionally observed, but large-scale spread of submersed species continued to be hampered by grazing. 


\begin{tabular}{|c|c|c|c|}
\hline \multicolumn{4}{|c|}{$\begin{array}{l}\text { Table } 6 \\
\text { Number of Aquatic Plant Colonies Surviving at the End of } 1998 \\
\text { Growing Season in Arcadia Lake }\end{array}$} \\
\hline Common Name & Tomato or Ring Cages & Orange Cages & Pen \\
\hline Wild celery (Texas) & 4 & 1 & 1 \\
\hline American pondweed & 62 & 16 & 7 \\
\hline Water stargrass & 41 & 4 & 6 \\
\hline Spatterdock & 12 & 2 & \\
\hline White water lily & 14 & 2 & \\
\hline Arrowhead & 5 & & \\
\hline Bulltongue & 21 & & \\
\hline Water willow & 30 & & \\
\hline Flatstem spikerush & 26 & & \\
\hline Squarestem spikerush & 19 & & \\
\hline Softstem bulrush & 35 & & \\
\hline Tall burhead & 8 & & \\
\hline Lizards tail & 6 & & \\
\hline Pickerelweed & 17 & & \\
\hline Water hyssop & 5 & & \\
\hline Total & 305 & 25 & 14 \\
\hline
\end{tabular}

Plants behind cove fences were limited to small colonies within tomato cages in early 1998. After carp densities were reduced and fences repaired, new potted plants were added. These plants initially established well, regardless of being additionally protected with tomato cages, while at the same time existing colonies began to spread from tomato cages. However, breaches in the cove fences evidently allowed entry by common carp and turtles, and some of these colonies were in decline before water levels left them exposed in August. New breaches in the fences were repaired during low-water conditions. Emergent species colonies established from potted plants inside (1997 and 1998) and outside (1998) of tomato cages recovered after water returned to normal levels. Spread from cove fences to unprotected areas was not observed. Potted plants in shoreline fences had also become well established initially, forming single colonies (individuals were no longer distinguishable). None of these was additionally protected with tomato cages. No declines were observed before exposure in August, and many species recovered and were filling the protected areas after water levels returned to normal. Greater establishment and recovery success in pens and shoreline fences (relative to cove fences) was attributed to the absence of or much lower densities of common carp. Evidently, fences across an entire cove were more susceptible to damage by floating debris (logs, etc.) and beaver activity, both of which permitted entry by common carp.

American pondweed and water stargrass were the most successful submersed species during the second year. Both established and began to spread within protected areas, and new colonies, albeit small and in very shallow water, of both (from fragments or seeds) were found behind all cove fences. In addition, both species recovered from low-water conditions. Illinois pondweed established 
quickly in areas with unbreached protection but did not fair well when breaches occurred. Recovery of Illinois pondweed following low water was poor. Wild celery failed to establish well in pens during 1998 (with one exception), although a few colonies planted in 1997 remained strong and recovered from low-water conditions. No elodea, sago pondweed, or coontail were observed by the end of 1998. Several southern naiad and muskgrass colonies were observed in tomato and orange cages following the low-water period, and in some cases, these had spread beyond small-scale exclosures.

Most spatterdock and white water lily planted in 1997 had not survived, and cages were replanted with those same species in 1998. Additional plants were installed at modified and new protected areas in June 1998, and by September, both had become established, and many colonies recovered following low-water levels. American lotus, which had exhibited poor survival during 1997 and did not survive into 1998, was planted at most sites using apical tips (along with potted white water lily and spatterdock) at the end of 1998.

Emergent species exhibited high survival and most had grown to fill tomato cages. Additionally, several species (water willow, bulltongue, arrowhead, flatstem spikerush and softstem bulrush) exhibited survival without protection, and these had grown beyond tomato cages into large-scale protected and unprotected areas. New colonies of several species, including bulltongue, arrowhead, flatstem spikerush, and softstem bulrush, were observed behind cove fences, apparently the result of seed dispersal and germination. Only two of the new species tested in 1998 (water hyssop and lizard's tail) exhibited high survival in protected areas, with water hyssop spreading from cages into larger-scale protected and unprotected areas.

Colonies were established at most sites in Arcadia Lake by the end of the second growing season. Fifteen (15) of the 21 species of aquatic plants tested survived, grew, and spread successfully within protective exclosures. In addition to tested species, southern naiad and muskgrass had established along with most submersed and floating-leaved plant colonies. At some sites, new colonies of some species were developing near the original transplants, exhibiting the early stages of founder colony spread. These colonies not only withstood low-water conditions, but also exhibited spread in the presence of grazers. Some species were not exhibiting spread beyond protective areas, but colonies had survived low-water conditions and intermittent periods of grazing (following breaches in cages). Table 7 provides the species comprising established founder colonies in Arcadia Lake.

\section{Assessment}

An assessment was conducted during June 1999 to ascertain recovery of aquatic plant colonies exposed to desiccation during fall 1998. As in 1998 assessments, focus was placed on establishment of plant colonies as opposed to survival of individual plants. All sites were visited and visible colonies were mapped using GPS technology. This assessment was the last officially scheduled as part of the Section 1135 Aquatic Habitat Restoration Project. 


\begin{tabular}{|c|c|c|c|}
\hline Common Name & Crom $50 \mathrm{~m}$ & Drotontion & conor \\
\hline American pondweed & Submersed & 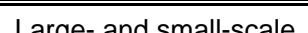 & 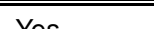 \\
\hline Water stargrass & Submersed & Large- and small-scale & Yes \\
\hline Wild celery & Submersed & Large-scale & No \\
\hline Southern naiad & Submersed & Large- and small-scale & No \\
\hline Muskgrass & Submersed & Large- and small-scale & No \\
\hline White water lily & Floating-leaved & Small-scale & Yes \\
\hline Spatterdock & Floating-leaved & Small-scale & No \\
\hline Bulltongue & Emergent & Small-scale & Yes \\
\hline Arrowhead & Emergent & Small-scale & Yes \\
\hline Water willow & Emergent & Small-scale & Yes \\
\hline Flatstem spikerush & Emergent & Small-scale & Yes \\
\hline Squarestem spikerush & Emergent & Small-scale & Yes \\
\hline Softstem bulrush & Emergent & Small-scale & Yes \\
\hline Tall burhead & Emergent & Small-scale & Yes \\
\hline Pickerelweed & Emergent & Small-scale & Yes \\
\hline Lizard's tail & Emergent & Small-scale & Yes \\
\hline Water hyssop & Emergent & Small-scale & Yes \\
\hline
\end{tabular}

Seventeen (17) of the 22 tested species (77 percent) were established by 1999. One species observed in 1998 (water hyssop) was not recorded in 1999, although two observed in 1999 (sago pondweed and water pepper) were thought to have not survived through 1998 . These species most likely had not recovered low-water periods in 1998, but remained viable through the winter and exhibited recovery in 1999. A third species recorded in 1999 but not in 1998 was American lotus, which was planted from apical tips at the end of 1998. In addition to tested species, southern naiad and muskgrass had established along with most submersed and floating-leaved plant colonies. No establishment of potted wild celery plants from Tennessee, wild celery tubers from Wisconsin, American pondweed tubers, Illinois pondweed, elodea, potted American lotus plants, slender spikerush, or water hyssop was observed.

Over 500 colonies of submersed, floating-leaved, and emergent plant species had been established at the 15 sites by June 1999 (Table 8). American pondweed colonies were the most common of submersed species, spatterdock the most common of floating-leaved species, and softstem bulrush the most common of emergent species. Although most colonies were inside protective exclosures, many species exhibited spread beyond to unprotected areas. Signs of herbivory by carp, turtles, and beaver were common on plants in unprotected areas. 


\begin{tabular}{|c|c|c|c|c|c|c|c|c|c|c|c|c|c|c|c|c|}
\hline \multicolumn{17}{|c|}{$\begin{array}{l}\text { Table } 8 \\
\text { Colonies (by species) Observed in June } 1999 \text { at } 15 \text { Sites in Arcadia Lake } \\
\end{array}$} \\
\hline \multirow[t]{2}{*}{ Common Name } & \multicolumn{16}{|c|}{ Site } \\
\hline & 1 & 2 & 3 & 4 & 5 & 6 & 7 & 8 & 9 & 10 & 11 & 12 & 13 & 14 & 15 & Total \\
\hline Wild celery (TX) & & & & & & 1 & & & & & & & & & 1 & 2 \\
\hline Wild celery (TN) & & & & & & & & & & & & & & & & 0 \\
\hline Wild celery (WI) & & & & & & & & & & & & & & & & 0 \\
\hline Am. pondweed (plant) & 1 & 24 & 2 & 6 & 3 & 12 & 6 & 41 & & 16 & 42 & 6 & 12 & 8 & 10 & 189 \\
\hline Am. pondweed (tuber) & & & & & & & & & & & & & & & & 0 \\
\hline Sago pondweed & & 1 & & & & 2 & & & & & & & & & & 3 \\
\hline Illinois pondweed & & & & & & & & & & & & & & & & 0 \\
\hline Water stargrass & 1 & 46 & 3 & & & 5 & 18 & 13 & & & & 1 & & 7 & 2 & 96 \\
\hline Southern naiad $^{1}$ & & & & & & & & & & & & & & & & - \\
\hline Muskgrass $^{1}$ & & & & & & & & & & & & & & & & - \\
\hline Elodea & & & & & & & & & & & & & & & & 0 \\
\hline Spatterdock & & & & 4 & & 2 & & & 1 & 2 & 3 & 1 & 3 & & 2 & 18 \\
\hline White water lily & & 3 & 2 & & & & & 2 & 1 & 1 & 3 & & 1 & & & 13 \\
\hline American lotus (plant) & & & & & & & & & & & & & & & & 0 \\
\hline American lotus (tip) & & & & & & 2 & & & & & & & & & & 2 \\
\hline Arrowhead & & 1 & 1 & & 2 & 2 & & 1 & & & 1 & & & & & 8 \\
\hline Bulltongue & 4 & 1 & 1 & & 1 & 2 & & 3 & 9 & 3 & 9 & & & 1 & & 34 \\
\hline Water willow & 2 & 1 & 1 & & 1 & 5 & & 2 & 2 & 2 & 14 & & 1 & 1 & 3 & 35 \\
\hline Flatstem spikerush & 2 & 1 & 1 & & 2 & 2 & & 3 & 2 & 5 & 6 & & & 2 & & 26 \\
\hline Squarestem spikerush & & 1 & & & & 2 & & 1 & & 1 & 6 & & & 1 & & 12 \\
\hline Slender spikerush & & & & & & & & & & & & & & & & 0 \\
\hline Softstem bulrush & 22 & & 1 & & 3 & 2 & & 1 & 2 & 1 & 4 & & 1 & 3 & & 40 \\
\hline Tall burhead & & & & & & & & & & & 7 & & & & & 7 \\
\hline Water hyssop & & & & & & & & & & & & & & & & 0 \\
\hline Pickerelweed & 2 & 1 & 1 & & 7 & 2 & & 2 & 1 & 5 & 4 & & 1 & 2 & & 28 \\
\hline Water pepper & & & & & & & & & & 1 & & & & & & 1 \\
\hline Lizard's tail & & & & & & 1 & & & & & & & & & & 1 \\
\hline Total & 34 & 80 & 13 & 10 & 19 & 42 & 24 & 69 & 18 & 37 & 99 & 8 & 19 & 25 & 18 & 515 \\
\hline
\end{tabular}




\section{Site-by-Site Results}

This section provides portions of assessments made at each site during 1997,1998, and 1999. Because this project was an operational, not a scientific, endeavor, this information is included to lend insight to the relative successes and failures encountered during the course of the project. Information given here is an empirical summary of field observations.

\section{Site 1}

The initial design included 18 tomato cages installed at $0.6 \mathrm{~m}(1 \mathrm{ft})$ deep and planted with softstem bulrush. By July 1997 (about 8 weeks following planting), all protected individual plants had survived and were growing, filling about onehalf the area protected by each cage. Two of three plants installed without protection were gone, and the one remaining was damaged, evidently by grazing turtles. By September 1997, all cages were filled, and spread from most was observed (one cage and its colony was missing, either the result of wave action or human activity). However, spread showed evidence of grazing, and, for the most part plants appeared to be contained inside exclosures because of herbivory.

In June 1998, a shoreline fence was added to the site, enclosing several of the existing tomato cages. Tomato cages were added to the site, both inside and outside the shoreline fence, and planted with emergent and submersed species. By September 1998, all plants were exposed. Spread from the original softstem bulrush tomato cages was evident, with colonies averaging about $2 \mathrm{~m}(6.5 \mathrm{ft})$ in diameter, producing a near continuous line of plants along the shoreline. Lowwater conditions may have contributed to this spread. Bulltongue, pickerelweed, water willow, and flatstem spikerush planted in June had survived and had grown to fill tomato cages. American pondweed and water stargrass planted in tomato cages behind the shoreline fence were surviving, and American pondweed had spread beyond the tomato cages. Erosion beneath the shoreline fence was evident.

By June 1999, most colonies had recovered from low-water conditions in 1998, and the site supported 34 plant colonies (Figure 10). Softstem bulrush colony size had declined, evidently because of beaver herbivory on unprotected portions of the colonies following return to normal water levels. The shoreline fence had been breached by erosion, but softstem bulrush colony spread had persisted, covering about one-fourth of the protected area. The breach had 


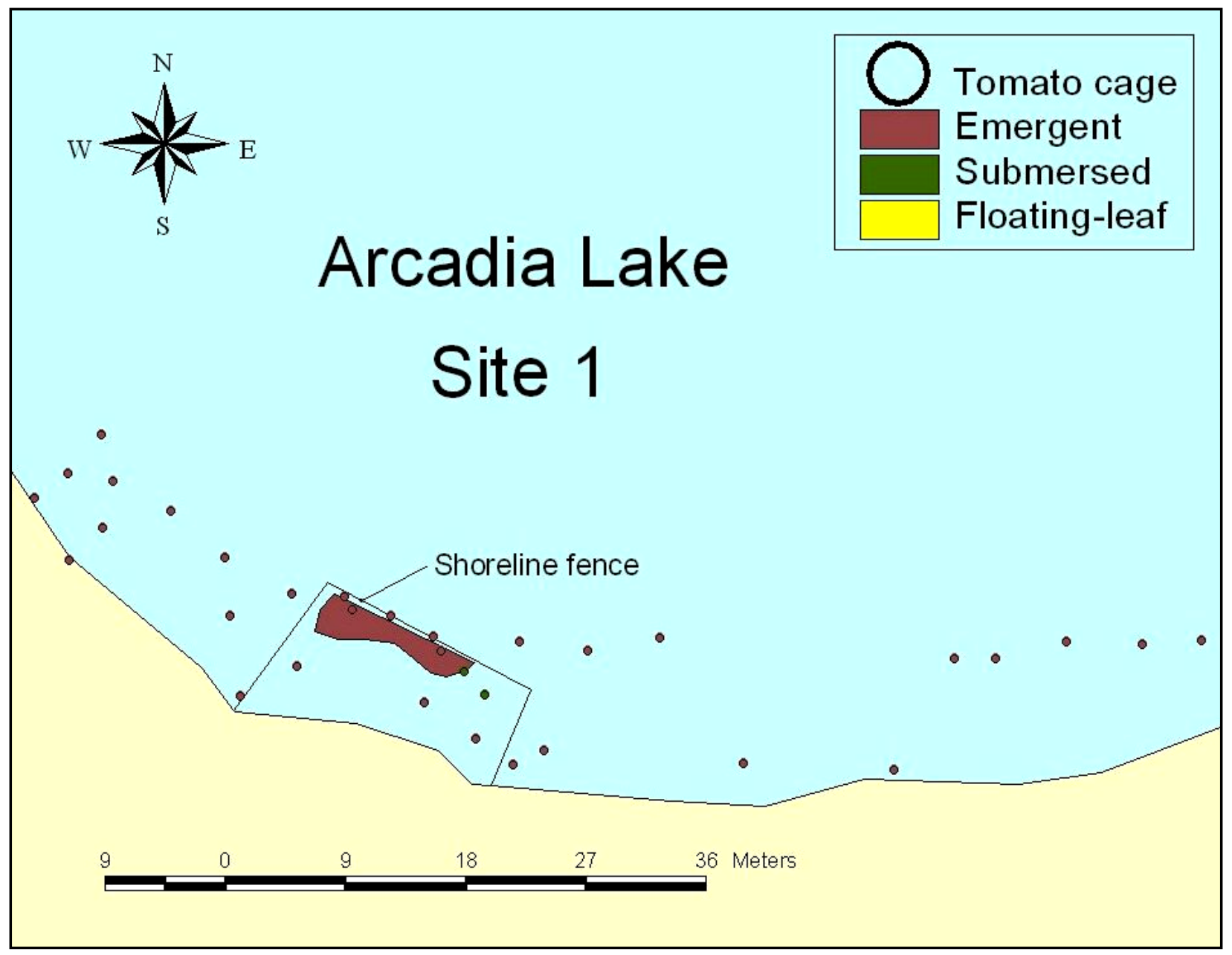

Figure 10. GPS mapping of aquatic plant colonies and protective exclosures was conducted at Site 1 in Arcadia Lake in June 1999

allowed possible access by common carp and turtles, and although they persisted inside tomato cages, American pondweed and water stargrass did not exhibit spread. Bulltongue, pickerelweed, water willow, and flatstem spikerush colonies filled tomato cages, although spread was minimal and apparently hampered by herbivory.

\section{Site 2}

The initial design included 48 tomato cages and 12 orange cages planted behind a cove fence, each planted with American pondweed, water stargrass, sago pondweed, or elodea. An additional six tomato cages (coontail), 12 ring cages (white water lily or spatterdock) and six orange cages (American pondweed, elodea) were planted outside the fence. By July 1997, the cove fence remained intact, although small herbivores evidently had passed through the 5- $\times 10$-cm $(2-\times 4$-in.) mesh. Although most tomato and orange cages contained plants, many showed signs of grazing, apparently by small turtles, carp, and 
crayfish, and many cages were empty. This was observed both inside and outside the cove fence. Empty cages were replanted with the same species originally planted. Interestingly, several small patches of American pondweed and sago

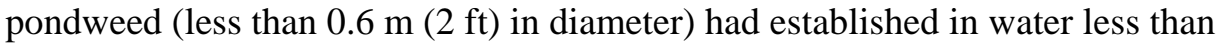
$0.15 \mathrm{~m}$ (6 in.) deep behind the cove fence, implying that herbivores were not feeding at those depths. In addition to the planted species, most tomato cages also contained southern naiad and muskgrass, evidently from seeds and spores transported in pots with the plants. Survival of coontail (tomato cages), white water lily (ring cages), and spatterdock (ring cages) outside the cove fence was high, perhaps indicating a lower order of preference by herbivores able to gain access through the mesh for those species. However, individuals of both floatingleaved species planted adjacent to the ring cages had disappeared, indicating larger herbivores were feeding on the two to the point of detriment. By September 1997, survival of American pondweed and water stargrass was similar to that in July, and the plants had grown to fill tomato cages. Survival of planted elodea and sago pondweed declined to zero, regardless the type of protection provided, although a 3-m- (9-ft-) diam patch of sago pondweed continued to thrive in shallow water at the back of the cove. Small herbivores with a preference for these two species apparently continued to affect their survival. It appeared that mortality for some species, including American pondweed, white water lily, and spatterdock could be attributed to fluctuating water levels and resultant snagging of stems on exclosure materials. Masses of dried stems and leaves of these species were hanging over the sides of many tomato and ring cages, and in some cases living plant material was not observed in those same cages. Although spatterdock survival was zero, white water lily survival remained high. Breaches under the cove fence and orange cages were noted and repaired. American pondweed patches in shallow water had expanded to cover diameters in excess of $3.05 \mathrm{~m}$ (10 ft) in two cases. Coontail had declined considerably, apparently the result of being washed away (it is a nonrooted species) by wave action.

In June 1998, new breaches beneath the cove fence were repaired and orange mesh was hung over the welded wire to reduce mesh size. Orange cage bottom flanges were reanchored to amend breaches. New tomato cages were installed behind the cove fence and planted with emergent species. By September 1998, many plants were exposed to desiccation. American pondweed and water stargrass shoots were visible in and out of tomato cages behind the cove fence. Although exposed, emergent species were surviving, and in most cases, individual plants installed inside and outside tomato cages had grown together to

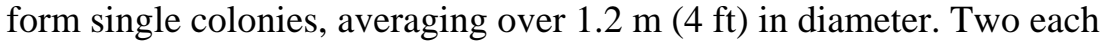
American lotus apical tips, white water lily pots, and spatterdock pots were planted behind the cove fence.

By June 1999, most colonies had recovered from low-water conditions in 1998, and the site supported 80 plant colonies (Figure 11). The cove fence had been breached, but many tomato and orange cages were filled with water stargrass and American pondweed. One tomato cage supported sago pondweed, which was not observed in 1998. Evidently, tubers were produced by some plants in 1997, and the low-water period in 1998 may have triggered sprouting. Spread by submersed species was minimal, apparently the result of carp gaining access behind the cove fence. White water lily was the only floating-leaved species 


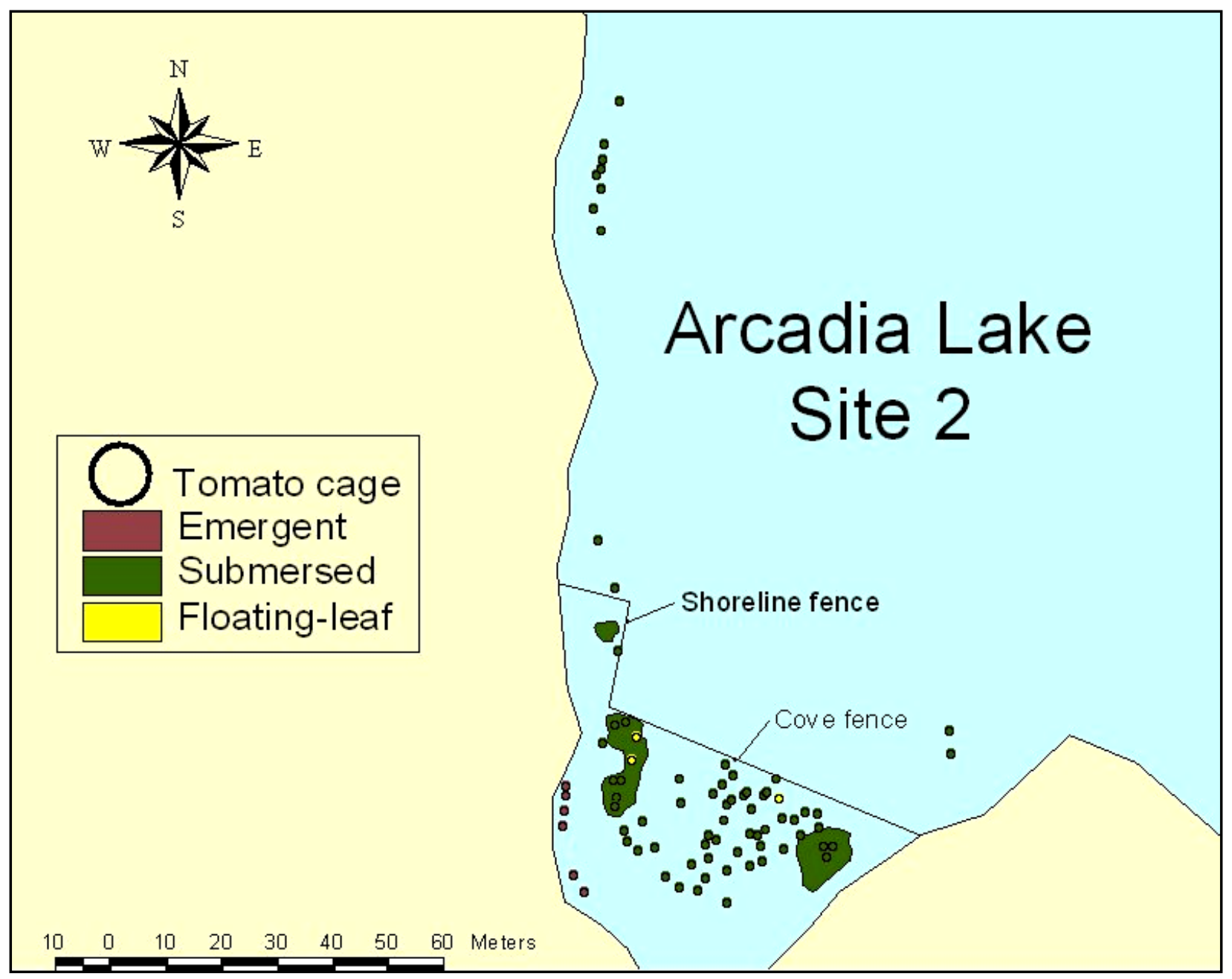

Figure 11. GPS mapping of aquatic plant colonies and protective exclosures was conducted at Site 2 in Arcadia Lake in June 1999

appearing to survive the late transplanting in 1998, and these had spread to cover areas as great as $10 \mathrm{~m}(30 \mathrm{ft})$ in diameter. Single arrowhead, bulltongue, water willow, flatstem spikerush, squarestem spikerush, and pickerelweed colonies were observed at this site, with each filling tomato cages, but spread by emergent species had not occurred.

\section{Site 3}

The initial design included 12 ring cages planted with white water lily and American pondweed or sago pondweed, with the less palatable white water lily serving as a "mask" for the herbivory-susceptible pondweeds. By July 1997, most white water lily had survived and grown to fill about 25 percent of each cage. Submersed species (American or sago pondweed) were present in most cages but were weak, apparently a result of competition with the white water lily. No replanting was undertaken at this site at that time. By September 1997, white 
water lily survival had declined, but those surviving filled their cages. No submersed species remained in any cage.

In June 1998, a shoreline fence was added, enclosing existing tomato cages. Tomato cages were added to the site and planted with emergent species. By September 1998, most plants were exposed. American pondweed and water stargrass shoots were visible in and out of tomato cages behind the shoreline fence. Although exposed, flatstem spikerush, bulltongue, water willow, softstem bulrush, lizard's tail, pickerelweed, and white water lily exhibited 100-percent survival. Lizard's tail, softstem bulrush, and water willow had spread, reaching colony sizes of about $1 \mathrm{~m}$ (3.2 ft) in diameter. Two American lotus apical tips were planted behind the shoreline fence.

By June 1999, most colonies had recovered from low-water conditions in 1998, and the site supported 13 plant colonies (Figure 12). Although the shoreline fence was damaged by a large, floating log, it apparently was not breached.

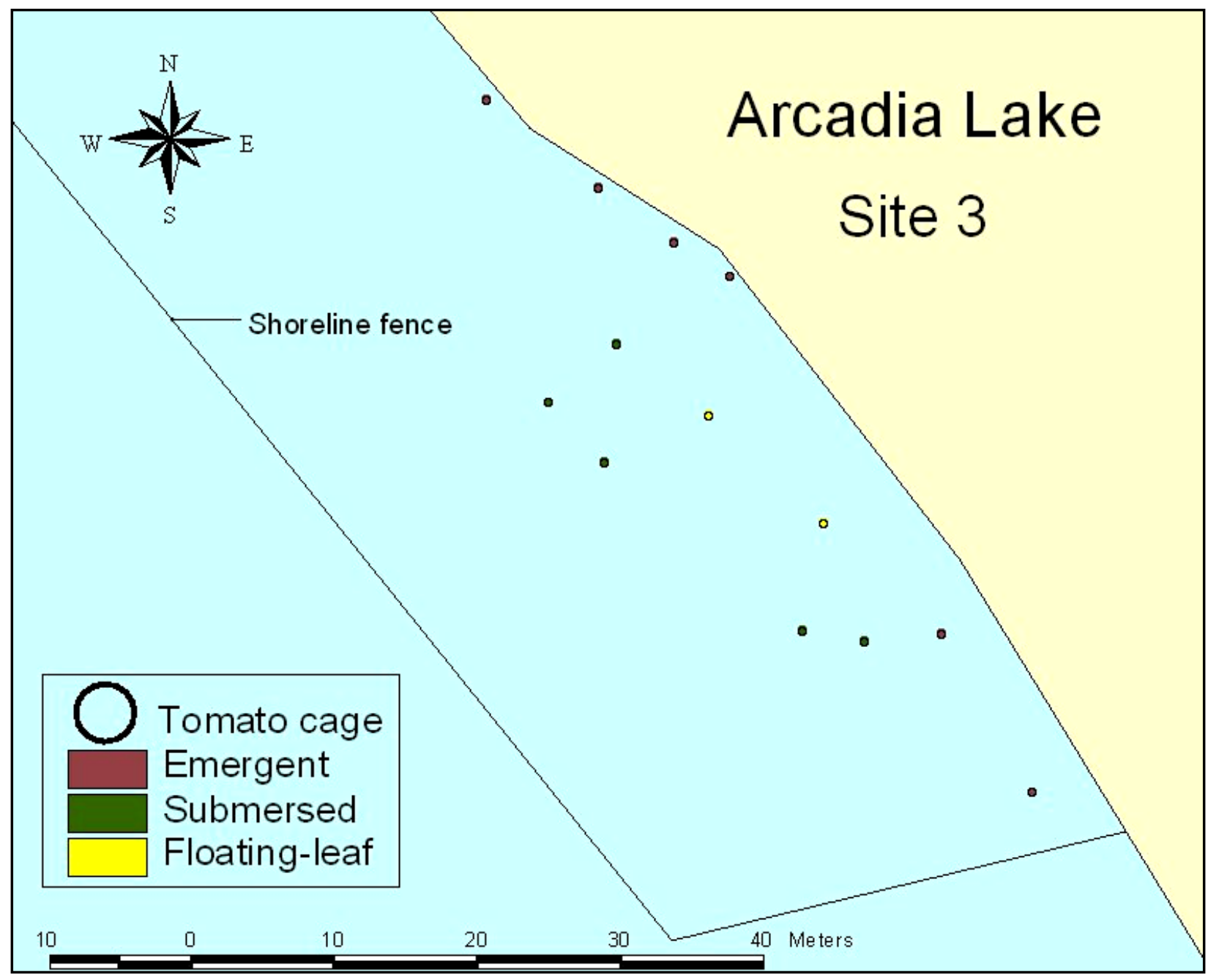

Figure 12. GPS mapping of aquatic plant colonies and protective exclosures was conducted at Site 3 in Arcadia Lake in June 1999 
However, high water during Spring 1999 apparently permitted entry by common carp, which were observed inside. Colonies of American pondweed, water stargrass, white water lily, arrowhead, bulltongue, water willow, flatstem spikerush, softstem bulrush, and pickerelweed were present inside tomato cages but had not spread beyond, evidently because of carp herbivory.

\section{Site 4}

The initial design included a cove fence, with six American pondweed planted with protection (tomato cages) and six planted without protection. By July 1997, most plants inside cages and all plants outside cages were gone. Crayfish were observed inside one cage, and mortality was attributed to grazing. Empty cages were replanted with American pondweed at that time. By September 1997, about one-half the American pondweed in tomato cages survived, but all were severely grazed by crayfish. Two cages were replanted, two were covered with 3.8-cm (1.5-in.) mesh sleeves and replanted, and two were covered with 0.6 -cm- (0.25-in.-) (nominal) mesh sleeves and replanted to assess the ability of finer meshes to exclude crayfish.

In June 1998, the cove fence had been damaged (by floating logs), and was repaired and wrapped with orange fencing. Four large ring cages about $1.5 \mathrm{~m}$ (5 ft) in diameter) were added and planted with spatterdock. By September 1998, tomato cages planted with American pondweed were exposed, and no plants were visible. All four spatterdock cages remained in shallow water and supported plants. A single potted white water lily plant was added to each spatterdock cage.

By June 1999, most colonies had recovered from low-water conditions in 1998, and the site supported 10 plant colonies (Figure 13). The cove fence was not breached at this site. American pondweed persisted inside tomato cages, but had only spread minimally, and plants growing outside tomato cages exhibited signs of turtle grazing. Four spatterdock colonies remained inside ring cages, but spread had not occurred.

\section{Site 5}

The initial design included 12 tomato cages planted with pickerelweed and an unplanted pen (for assessing lake seedbank). By July 1997, survival was high, with all but one plant surviving in tomato cages. Plants filled about 25percent of each cage. No replanting was undertaken at that time. No plants were observed in the unplanted pen, indicating no or limited seedbank in the lake. By September 1997, survival was moderate, with just over one-half the plants surviving. Surviving plants had filled tomato cages but could not spread beyond the cages because of herbivores. Grazing damage appeared to be caused by waterfowl, possibly resident Canada geese. No plants were observed in the unplanted pen. 


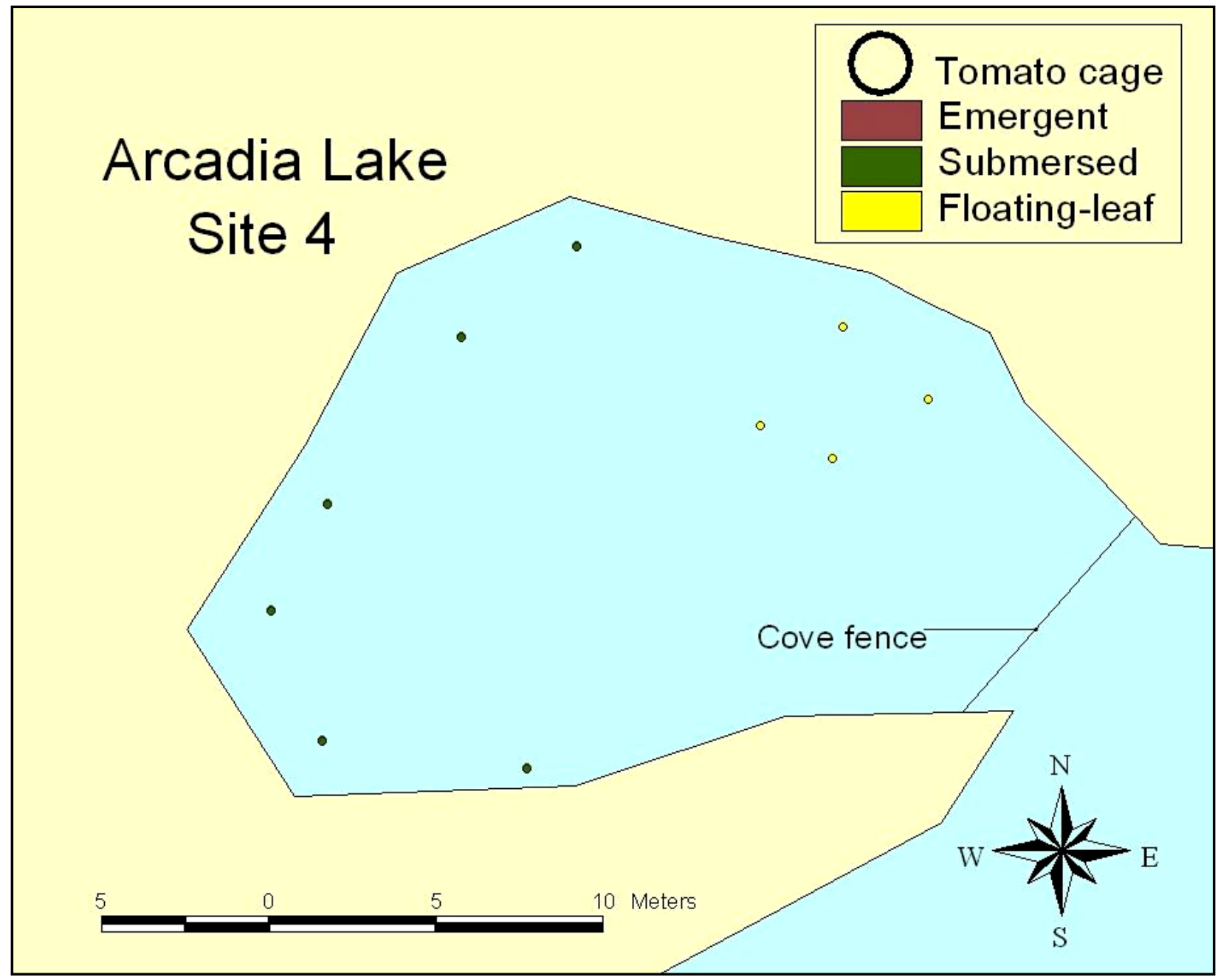

Figure 13. GPS mapping of aquatic plant colonies and protective exclosures was conducted at Site 4 in Arcadia Lake in June 1999

In June 1998, tomato cages were added to the site and planted with emergent species. The pen was planted with American pondweed. By September 1998, tomato cages were exposed but continued to support emergent plants, including pickerelweed, flatstem spikerush, squarestem spikerush, softstem bulrush, bulltongue, water willow, and lizard's tail. Softstem bulrush, pickerelweed, and

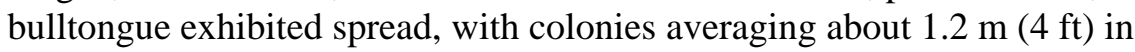
diameter. Although more than one-half was exposed, American pondweed covered about 75 percent of the pen. Two American lotus apical tips and one each potted spatterdock and white water lily were planted in the pen. Two unprotected water willow and softstem bulrush were planted in $15 \mathrm{~cm}$ (6 in.) of water just behind the pen.

By June 1999, most colonies had recovered from low-water conditions in 1998, and the site supported 19 plant colonies (Figure 14). American pondweed completely filled the pen at this site, which was not breached. American pondweed, arrowhead, bulltongue, water willow, flatstem spikerush, softstem bulrush, and pickerelweed persisted inside tomato cages but had only spread minimally, 


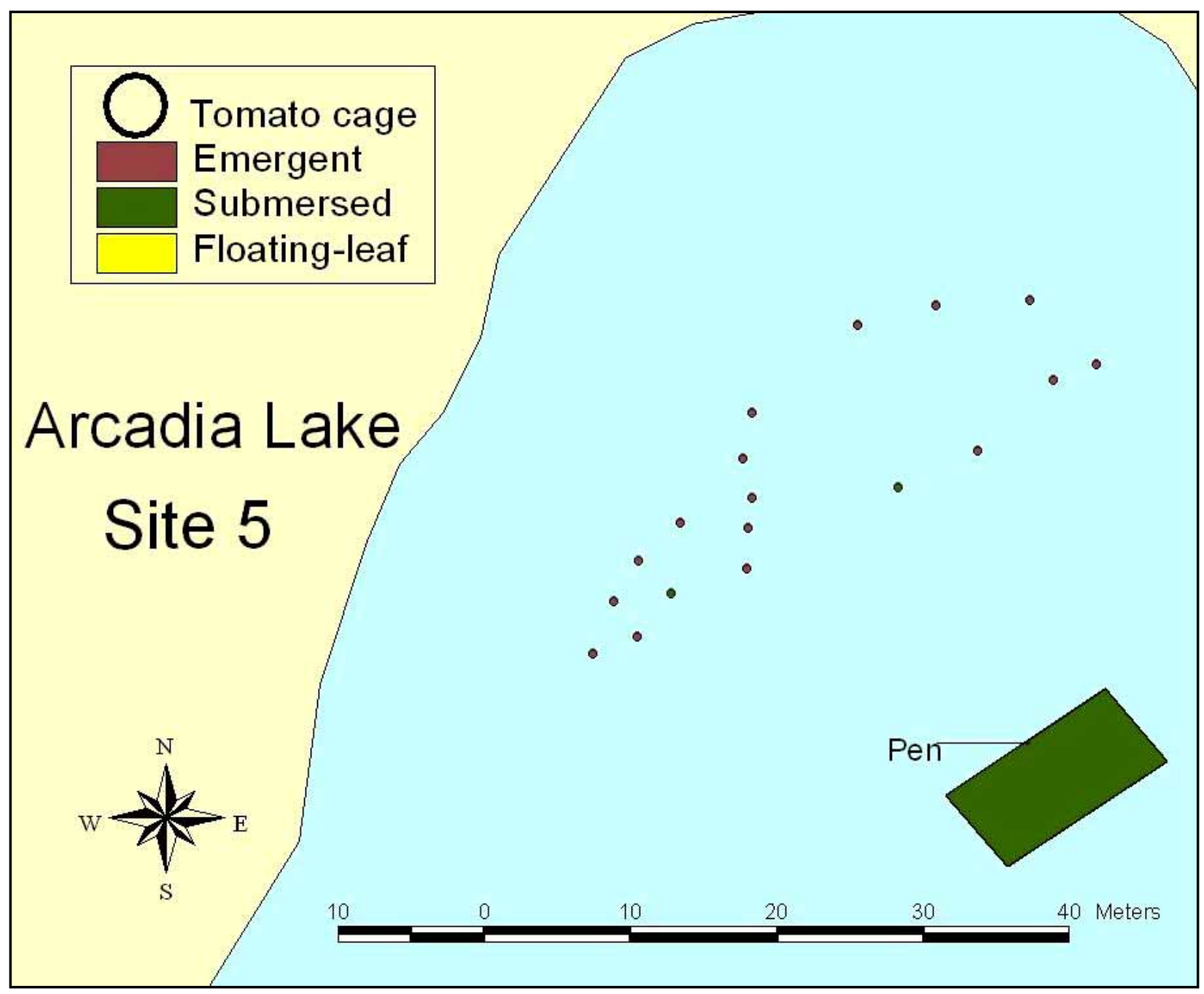

Figure 14. GPS mapping of aquatic plant colonies and protective exclosures was conducted at Site 5 in Arcadia Lake in June 1999

with portions of plants growing outside cages exhibiting signs of grazing by carp, turtles, and waterfowl (resident Canada geese).

\section{Site 6}

The initial design included 12 tomato cages planted with American pondweed, and four (4) pens, with each one-half of each pen planted with American pondweed, sago pondweed, elodea, or water stargrass. By July 1997, American pondweed survival in tomato cages was good, with only one cage requiring replanting. American pondweed, elodea, and water stargrass were present in pens, each covering about 10 percent of the protected area in which it was planted. Sago pondweed was not evident at that time but was not replanted. By September 1997, American pondweed survival in tomato cages remained good, and plants nearly filled the cages. American pondweed and water stargrass were 
the only plants remaining in pens, and coverage had increased to nearly 100 percent and 75 percent, respectively.

In June 1998, fences were added to tie three of the four pens together, producing a large, sectioned pen, thereby expanding the protected area at the site. The pen was additionally planted with American pondweed, water stargrass, and wild celery. Tomato cages were added to the site and planted with submersed, floating-leaved, and emergent species. By September 1998, most tomato cages were exposed but continued to support emergent species and American pondweed. In some cases, spread from the tomato cages had occurred, including softstem bulrush, flatstem spikerush, and white water lily. Although pens were partially exposed, each was nearly 100-percent filled with plants, predominantly American pondweed and water stargrass, although one pen exhibited about 25-percent coverage of wild celery. Four American lotus apical tips and one each potted spatterdock and white water lily were planted in the pen.

By June 1999, many colonies had recovered from low-water conditions in 1998, and the site supported 42 plant colonies (Figure 15). American pondweed and water stargrass dominated the joined pens at this site, with small colonies of wild celery and American lotus present. American pondweed filled the single small pen that had not been joined to the other three original pens. No pens appeared to be breached. American pondweed, spatterdock, arrowhead, bulltongue, water willow, flatstem spikerush, squarestem spikerush, softstem bulrush, pickerelweed, and lizard's tail persisted inside tomato cages, but spread was minimal. Three water willow colonies (planted without protection in 1998) persisted. One small, unprotected pickerelweed colony was found in very shallow water at the back of the cove, evidently the result of spread by seed.

\section{Site 7}

The initial design included 12 tomato cages planted with American lotus. By July 1997, no American lotus had survived. However, several cages contained small American pondweed plants, apparently having grown from seed included in the sediments in which the lotus was cultured. It appeared that sunfish had chosen the stem and root mass of lotus as spawning substrate, dug out most sediment, and deposited eggs. Whether or not this caused mortality is unknown. Tomato cages were planted with water stargrass at this time. By September 1997, water stargrass survival was high, and only one cage required replanting.

By June 1998, water stargrass survival remained high, and six tomato cages (with small mesh sleeves) were added to the site, each planted with both water stargrass and American pondweed. By September 1998, most tomato cages were exposed, all continued to support water stargrass, and spread from cages had occurred, with colonies averaging about $0.9 \mathrm{~m}$ (3 ft) in diameter. About one-half the cages additionally planted with American pondweed continued to support that species, and in most cases the American pondweed had grown beyond the cages, forming colonies up to $2 \mathrm{~m}$ (6.5 ft) in diameter. Two each water willow and softstem bulrush plants were planted without protection in $0.15 \mathrm{~m}$ (6 in.) of water at this site. 


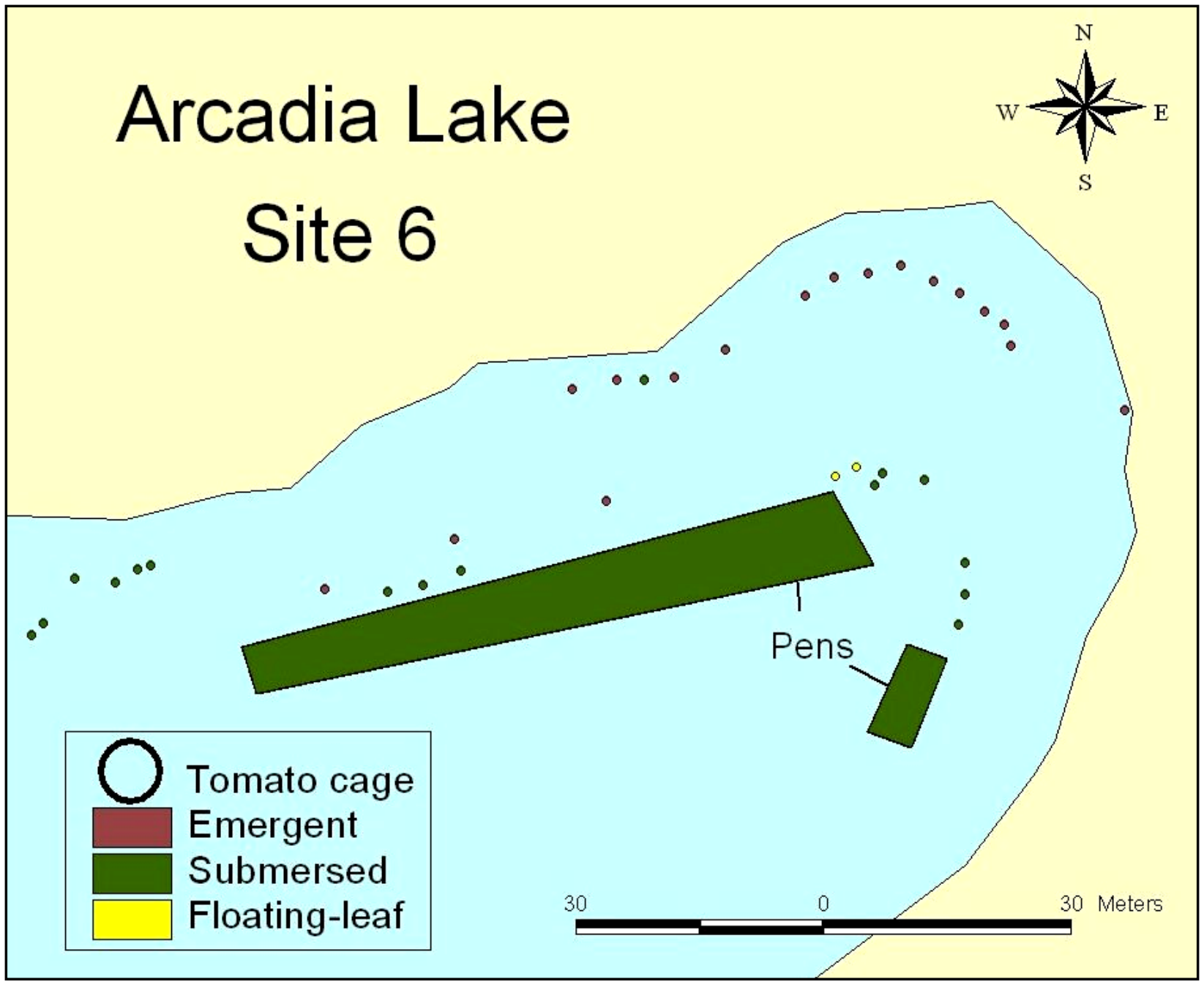

Figure 15. GPS mapping of aquatic plant colonies and protective exclosures was conducted at Site 6 in Arcadia Lake in June 1999

By June 1999, most colonies had recovered from low-water conditions in 1998, and the site supported 24 plant colonies (Figure 16). Water stargrass and American pondweed persisted inside tomato cages, but spread from cages was minimal. However, several new colonies of water stargrass averaging about $1 \mathrm{~m}$ (3 ft) in diameter, apparently established from fragments, were founding growing at this site.

\section{Site 8}

The initial design included 30 tomato cages (planted with elodea or American pondweed) and 8 orange cages (planted with elodea or American pondweed) installed behind a cove fence. In addition, six tomato cages and four orange cages were installed outside the fence and planted with American pondweed. Four ring cages were planted outside the fence with spatterdock. By July 1997, the cove fence was breached by beavers, and carp and turtles were observed behind the 


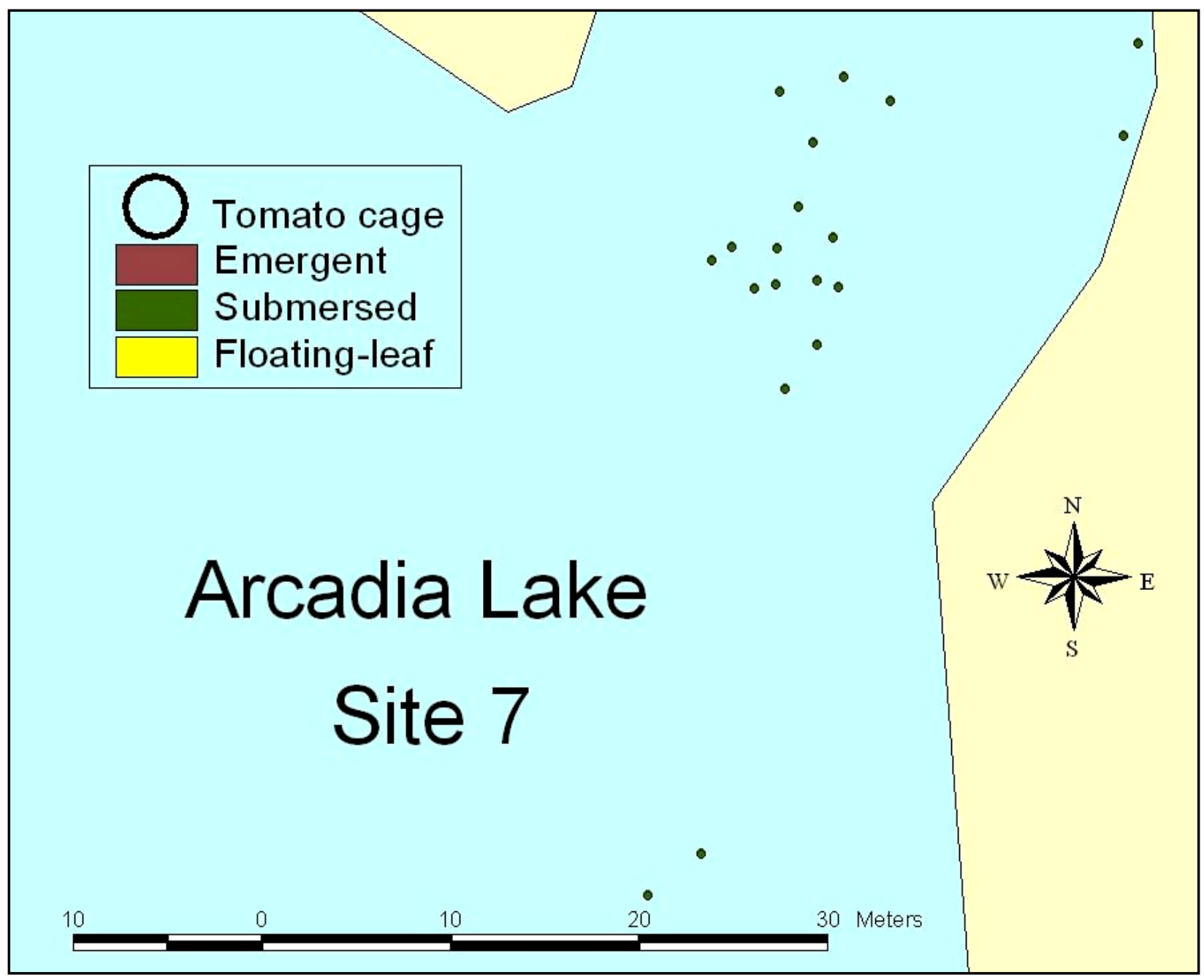

Figure 16. GPS mapping of aquatic plant colonies and protective exclosures was conducted at Site 7 in Arcadia Lake in June 1999

fence. Most tomato and orange cages no longer contained plants (American pondweed or elodea), and those that did showed signs of grazing, apparently by small turtles, carp, and crayfish. This was true both inside and outside the cove fence. The fence and breached orange cages were repaired, and empty cages were replanted with the species originally planted in each. Spatterdock survival outside the cove fence was high. By September 1997, the cove fence was again breached by beavers, and repairs were made. Elodea was found surviving in only one orange cage, and American pondweed survived in only about one-half the tomato cages and orange cages in which it was planted. Evidence of grazing by turtles or crayfish was present in most cages. A fall-in, floating turtle trap $(2.5-\times 5$-cm (1- $\times 2$-in.) mesh) had been set behind the cove fence 2 weeks prior to the assessment, and upon checking it, 42 red-eared sliders had been caught (these turtles were removed to another cove and released). Most empty cages were replanted with apical tips of the same species collected from existing colonies at that time eight of these were additionally protected with small-mesh sleeves. Spatterdock survival outside the cove fence remained high, although there was evidence of turtle grazing on leaves outside the cages. 
In June 1998, the cove fence was breached by beavers, and repairs were made. Tomato and ring cages were added behind the cove fence and planted with emergent and floating-leaved species. Eight 1997 tomato cages were covered with small mesh sleeves. By September 1998, nearly all plants were exposed, and the fence had again been breached by beavers. American pondweed and water stargrass shoots were visible in and out of tomato and orange cages behind the cove fence (regardless inclusion of sleeves). Although exposed, emergent species were surviving and, in most cases, had filled cages and were beginning to spread (softstem bulrush, water willow, flatstem spikerush, and bulltongue). Squarestem spikerush did not appear to survive at this site.

By June 1999, many colonies had recovered from low-water conditions in 1998, and the site supported 69 plant colonies (Figure 17). The cove fence had been breached, but many tomato and orange cages were filled with American pondweed and water stargrass. Spread by submersed species was minimal, apparently the result of carp gaining access behind the cove fence, although several small, unprotected colonies of water stargrass (apparently from

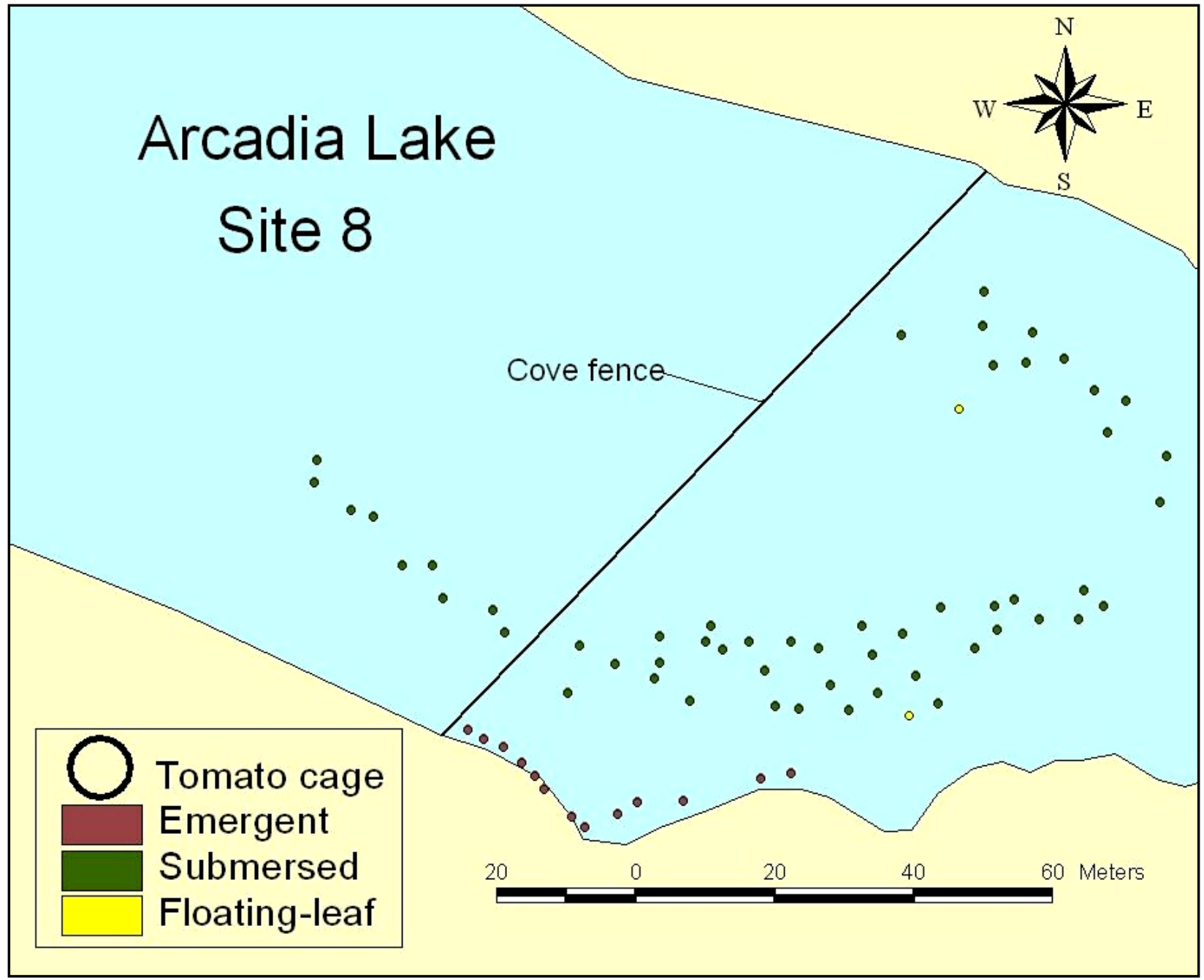

Figure 17. GPS mapping of aquatic plant colonies and protective exclosures was conducted at Site 8 in Arcadia Lake in June 1999 
fragments) were observed. White water lily was the only floating-leaved species observed, and these had not spread beyond orange cages. Colonies of arrowhead, bulltongue, water willow, flatstem spikerush, squarestem spikerush, softstem bullrush, and pickerelweed were observed at this site, with each filling tomato cages, but spreading by emergent species had not occurred.

\section{Site 9}

The initial design included 12 tomato cages planted with American lotus. By July 1997, no American lotus was surviving. Tomato cages were replanted with either elodea or American pondweed. By September 1997, American pondweed survival was high, but elodea was gone. Most pondweed plants exhibited evidence of turtle grazing inside the cages. Empty cages were replanted with American pondweed.

In June 1998, a shoreline fence enclosing several of the existing tomato cages was added and was planted with submersed and emergent species. Tomato cages were added to the site and planted with emergent and floating-leaved species. By September 1998, most of the area behind the fence was exposed to desiccation, and only one (1997) tomato cage supported American pondweed. Newer cages continued to support emergent and floating-leaved species, with softstem bulrush

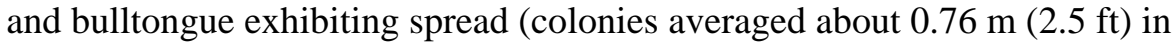
diameter).

By June 1999, most colonies had recovered from low-water conditions in 1998, and the site supported 24 plant colonies, although no submersed species survived (Figure 18). White water lily, spatterdock, bulltongue, water willow, flatstem spikerush, softstem bulrush, and pickerelweed persisted inside tomato cages, but spread from cages was minimal. One unprotected water willow plant, apparently grown from a fragment, was observed at this site.

\section{Site 10}

The initial design included 24 tomato cages (planted with American pondweed or elodea) and 8 orange cages (planted with American pondweed or elodea). By July 1997, survival was good for both species in tomato cages, although some required replanting. Most orange cages had been breached, and survival was poor, with the exception of a single cage planted with American pondweed that exhibited 100-percent coverage. Orange cages were repaired but not replanted. By September 1997, American pondweed survival was moderate in tomato and orange cages, but evidence of herbivory was visible in most cages. Elodea was found in only one orange cage. Most orange cages were breached, and repairs were made. Only American pondweed tomato cages were replanted at this time.

In June 1998, a shoreline fence was added and planted with submersed and emergent species. Orange cages not supporting American pondweed were planted with floating-leaved species. By September 1998, the shoreline pen was 


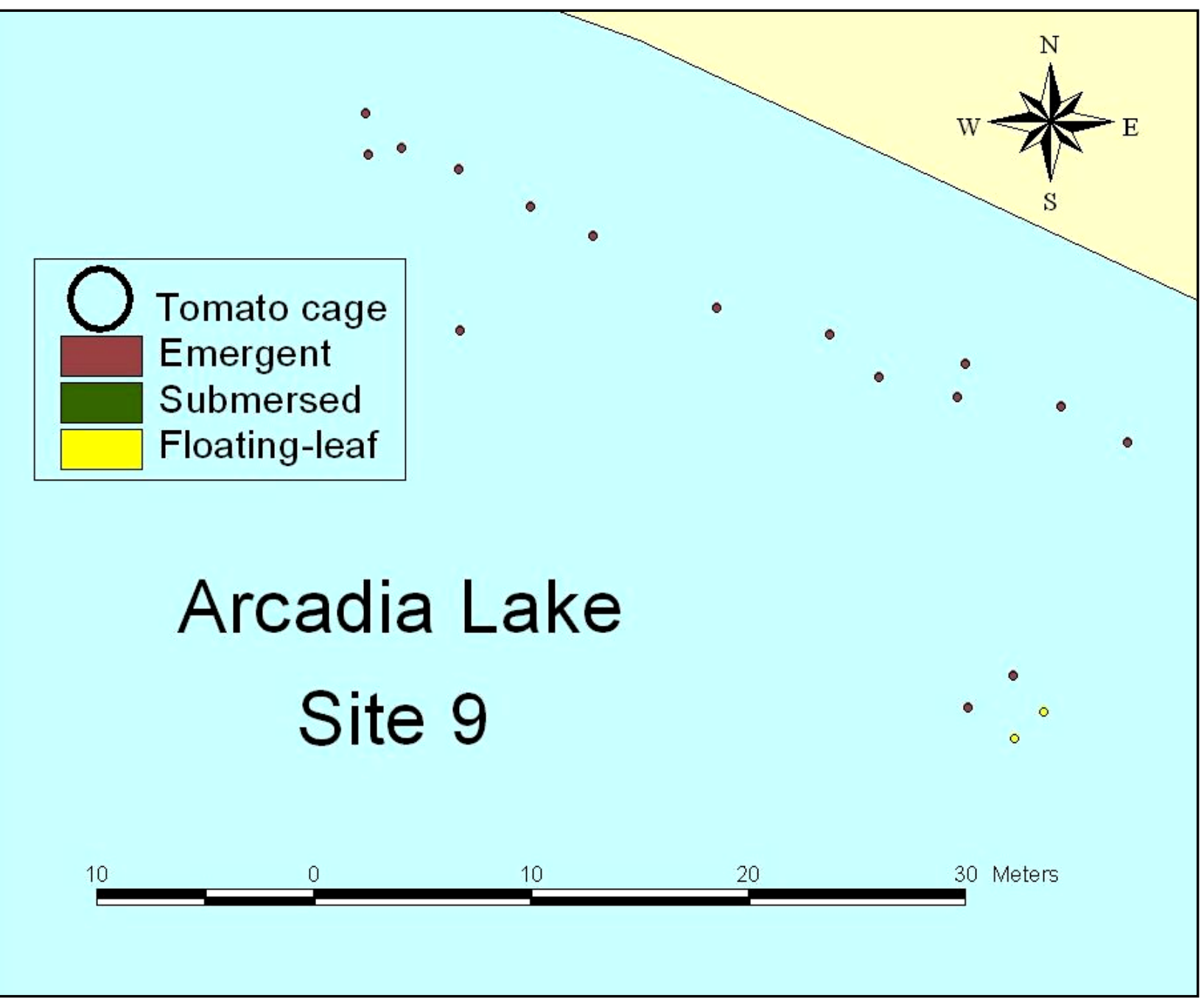

Figure 18. GPS mapping of aquatic plant colonies and protective exclosures was conducted at Site 9 in Arcadia Lake in June 1999

nearly dry, and only softstem bulrush, bulltongue, and pickerelweed had survived. Many tomato cages were dry, but American pondweed persisted in most. Elodea had not survived at this site. American pondweed, white water lily, and spatterdock had grown to nearly fill orange cages in which they were planted, although no spread had occurred.

By June 1999, most colonies had recovered from low-water conditions in 1998, and the site supported 37 plant colonies (Figure 19). The shoreline fence was not breached at this site. Colonies of American pondweed, white water lily, and spatterdock persisted in tomato cages. White water lily, bulltongue, water willow, flatstem spikerush, squarestem spikerush, softstem bulrush, pickerelweed, and water pepper planted behind the shoreline fence were present and

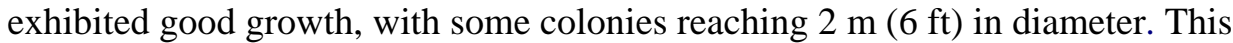
was the only site at which water pepper had established. 


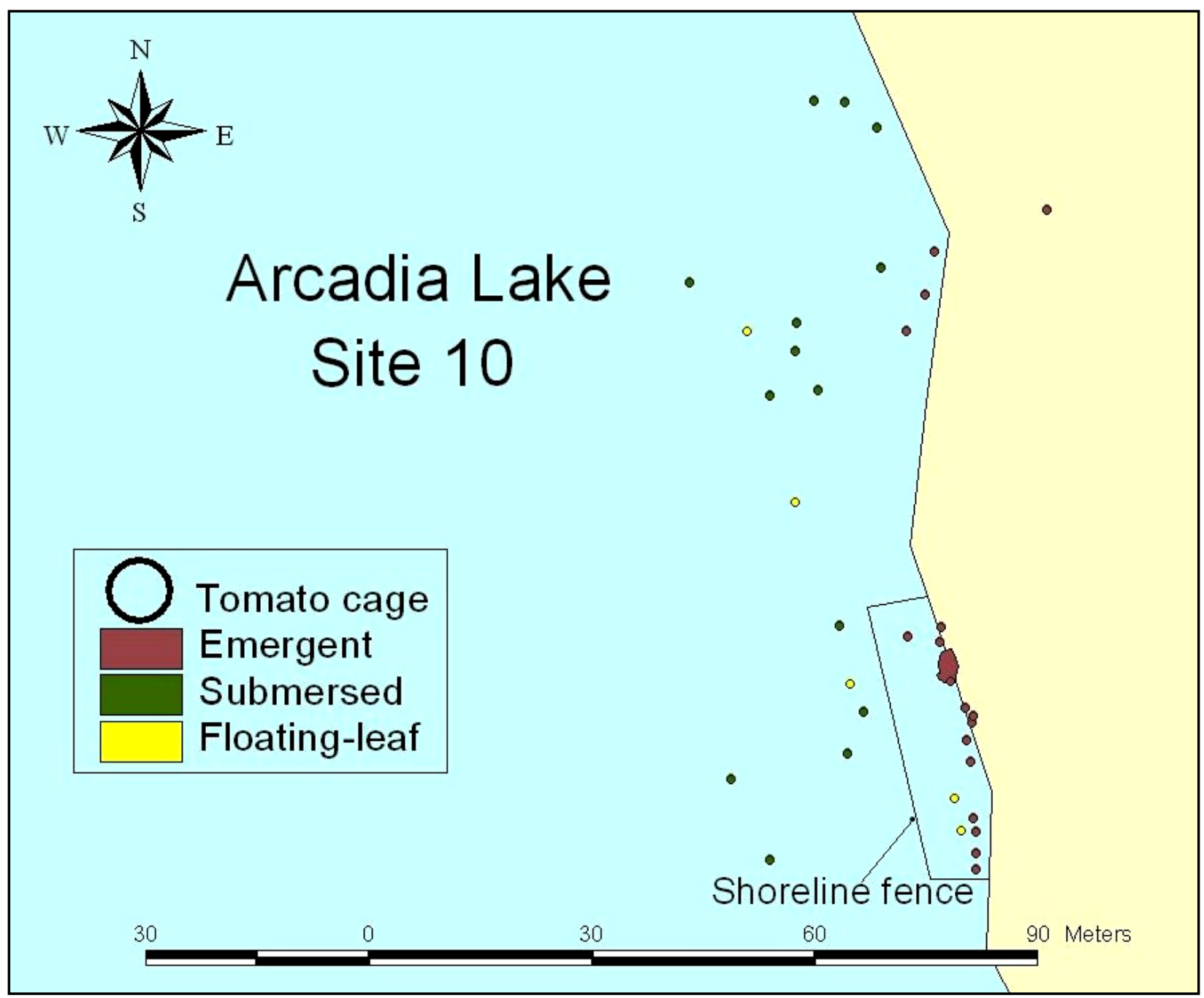

Figure 19. GPS mapping of aquatic plant colonies and protective exclosures was conducted at Site 10 in Arcadia Lake in June 1999

\section{Site 11}

The initial design included 60 tomato cages planted with American pondweed, elodea, or wild celery (from Texas, Tennessee, and Wisconsin), 8 orange cages planted with American pondweed or elodea, 48 tomato cages planted with softstem bulrush, bulltongue, arrowhead, pickerelweed, flatstem spikerush, squarestem spikerush, water willow, or tall burhead, all installed behind a cove fence. Six tomato cages and four orange cages were planted with American pondweed outside the cove fence. By July 1997, the cove fence was breached by beavers. Survival was good for American pondweed in tomato and orange cages, and good for elodea in tomato cages. Survival of elodea in orange cages was poor, apparently the result of turtles climbing over the cages (no breaches beneath cages were found). Turtles at this site were larger and apparently unable to pass through the mesh of tomato cages but were abundant enough to eliminate all submersed species test plants installed without protection. Texas and Tennessee ecotypes of wild celery exhibited good survival in tomato cages, but 
Wisconsin wild celery did not survive. This may have been caused by the failure of tubers to sprout or inappropriateness of the ecotype for Oklahoma. Emergent species (softstem bulrush, squarestem spikerush, tall burhead, arrowhead, bulltongue, pickerelweed, flatstem spikerush, and water willow) survived both in and out of tomato cages, but those inside were more robust, indicating that herbivory was affecting establishment. The exception was water willow, which did not appear to be affected whether protected or not. By September 1997, the cove fence was again breached by beavers, and repairs were made. Survival remained good for American pondweed in tomato and orange cages, and plants had grown to nearly fill cages. Elodea did not survive at this site, apparently the result of cage breaches and herbivores. Texas and Tennessee ecotypes of wild celery exhibited moderate survival in tomato cages, although both exhibited signs of turtle or carp grazing. Emergent species had high survival in tomato cages, and many had grown to fill them. Survival outside cages was lower, and plants were less robust than were protected individuals. Spread from cages by several species was observed, including softstem bulrush and water willow.

In June 1998, the cove fence was breached by beavers, and repairs were made. Tomato and ring cages were added behind the cove fence and planted with emergent and floating-leaved species, and empty cages were planted with either American pondweed or Illinois pondweed. Eight 1997 tomato cages were covered with small mesh sleeves. By September 1998, nearly all plants were exposed. American pondweed survival remained high, and all cages in which it was planted exhibited 100-percent coverage and some degree of spread. Illinois pondweed did not apparently survive the low-water period in August. Although exposed, floating-leaved and emergent species were surviving, and in most cases had filled cages. Many had spread from cages, forming colonies up to $2.4 \mathrm{~m} \mathrm{(8 \textrm {ft } )}$ in diameter, including bulltongue, squarestem spikerush, softstem bulrush, flatstem spikerush, water willow, and pickerelweed. Three American lotus apical tips, one white water lily pot, and one spatterdock pot were planted behind the cove fence.

By June 1999, many colonies had recovered from low-water conditions in 1998, and the site supported 99 plant colonies (Figure 20). The cove fence had been breached by beavers, but many tomato and orange cages were filled with American pondweed. Spread by submersed species was minimal, apparently because the carp gained access behind the cove fence. White water lily and spatterdock remained in orange cages, although spread was not observed. Colonies of arrowhead, bulltongue, water willow, flatstem spikerush, squarestem spikerush, softstem bulrush, tall burhead, and pickerelweed were observed at this site, with each filling tomato cages; water willow and softstem bulrush exhibited spread.

\section{Site 12}

The initial design included 12 tomato cages planted with American pondweed or water stargrass. By July 1997, survival was high for both species. Empty cages were replanted. By September 1997, most water stargrass was surviving, 


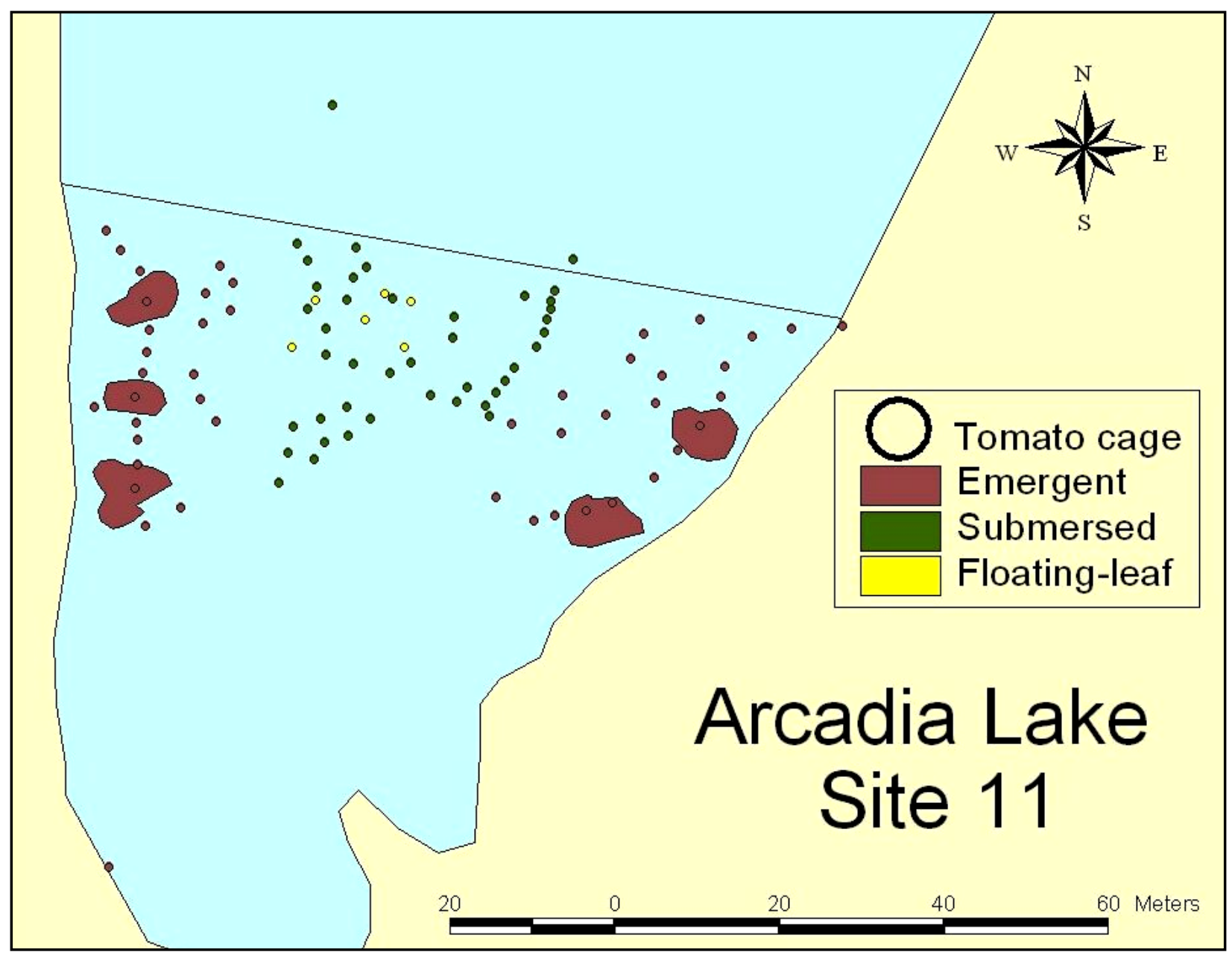

Figure 20. GPS mapping of aquatic plant colonies and protective exclosures was conducted at Site 11 in Arcadia Lake in June 1999

but only one American pondweed remained. Turtle herbivory was evident on remaining plants.

No modifications were made to this site in June 1998. Surviving plants appeared weak, and cages had apparently been breached by herbivores. By September 1998, only a single spatterdock plant remained in one cage. Three empty cages were planted with American lotus apical tips.

By June 1999, most colonies had recovered from low-water conditions in 1998, and the site supported eight plant colonies (Figure 21). American pondweed, water stargrass, and spatterdock continued to grow inside tomato cages, but plants were weak and no spread was observed. 


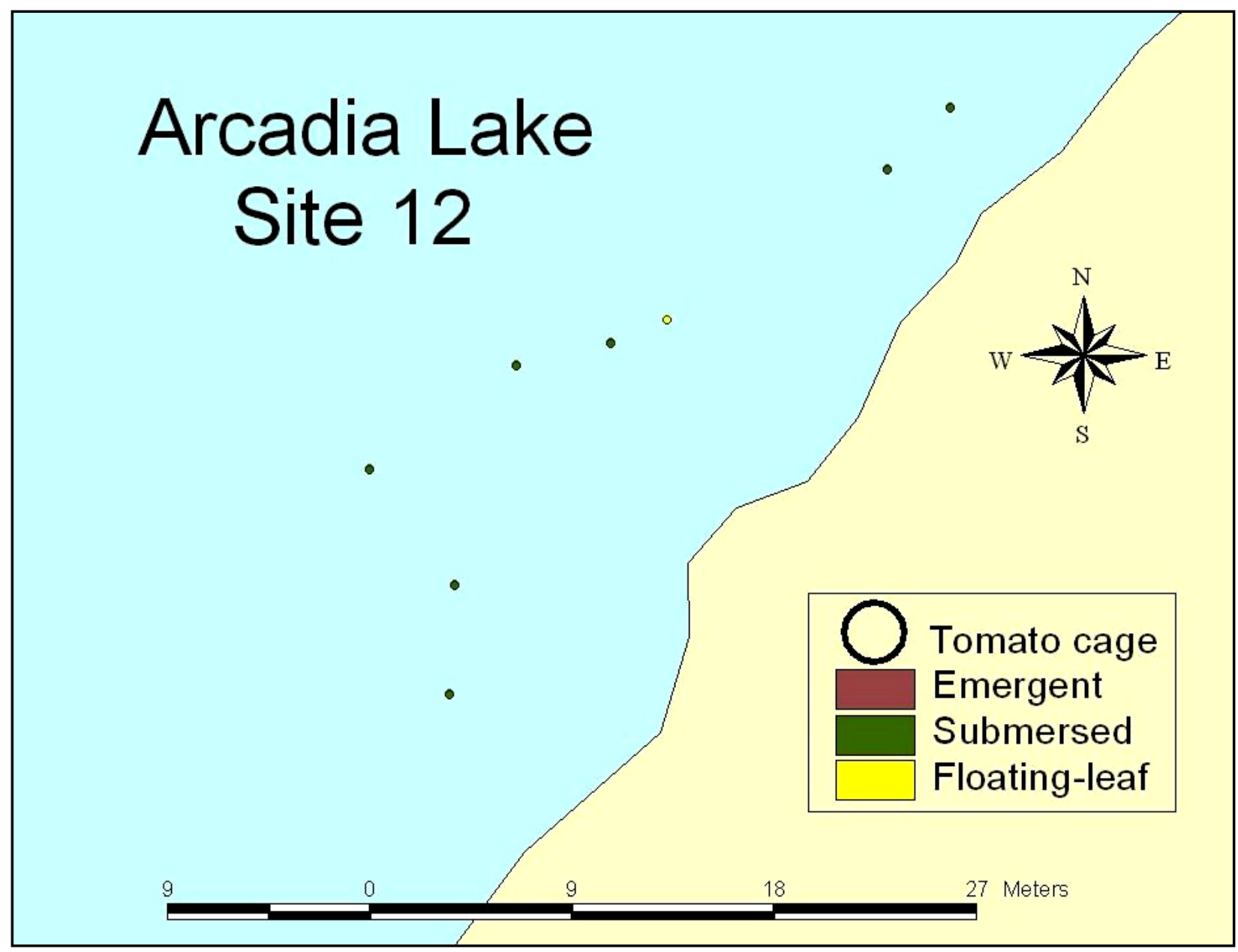

Figure 21. GPS mapping of aquatic plant colonies and protective exclosures was conducted at Site 12 in Arcadia Lake in June 1999

\section{Site 13}

The initial design included 16 tomato cages planted with American lotus and American pondweed, water stargrass, sago pondweed, or elodea. An additional 12 tomato cages were planted with American pondweed pots or tubers. Four ring cages were planted with spatterdock. By July 1997, most American lotus had died, but submersed species planted with it were surviving. Empty cages were replanted with the submersed species originally planted. American pondweed survival was high in tomato cages, regardless of propagule type (potted plant or tuber), although potted plant cages were much more vigorous, filling about 50 percent of each cage as opposed to 10 percent of each cage filled by tubergrown plants. Spatterdock survival in ring cages was high. By September 1997, American pondweed and water stargrass originally planted exhibited moderate survival, but elodea and sago pondweed were gone. Most cages had been tipped over by floating debris. American pondweed planted from pots had high survival, but pondweed planted from tubers had not survived. Spatterdock survival was moderate. 
In June 1998, a shoreline fence was added and planted with submersed and emergent species. Tomato cages were added to the site and planted with floatingleaved species. Sixteen (16) tomato cages were missing or heavily damaged by floating debris, and these were abandoned. Remaining tomato cages supported American pondweed, but no spread was observed. By September 1998, most tomato cages and the shoreline fence were exposed to desiccation. No submersed species were observed, but white water lily and spatterdock were surviving in tomato cages. Softstem bulrush and water willow persisted behind the shoreline fence.

By June 1999, most colonies had recovered from low-water conditions in 1998, and the site supported 19 plant colonies (Figure 22). The shoreline fence was not breached at this site. Colonies of American pondweed, white water lily, and spatterdock persisted in tomato cages. American pondweed, spatterdock, water willow, softstem bulrush, and pickerelweed planted behind the shoreline fence had recovered and appeared to be in good condition.

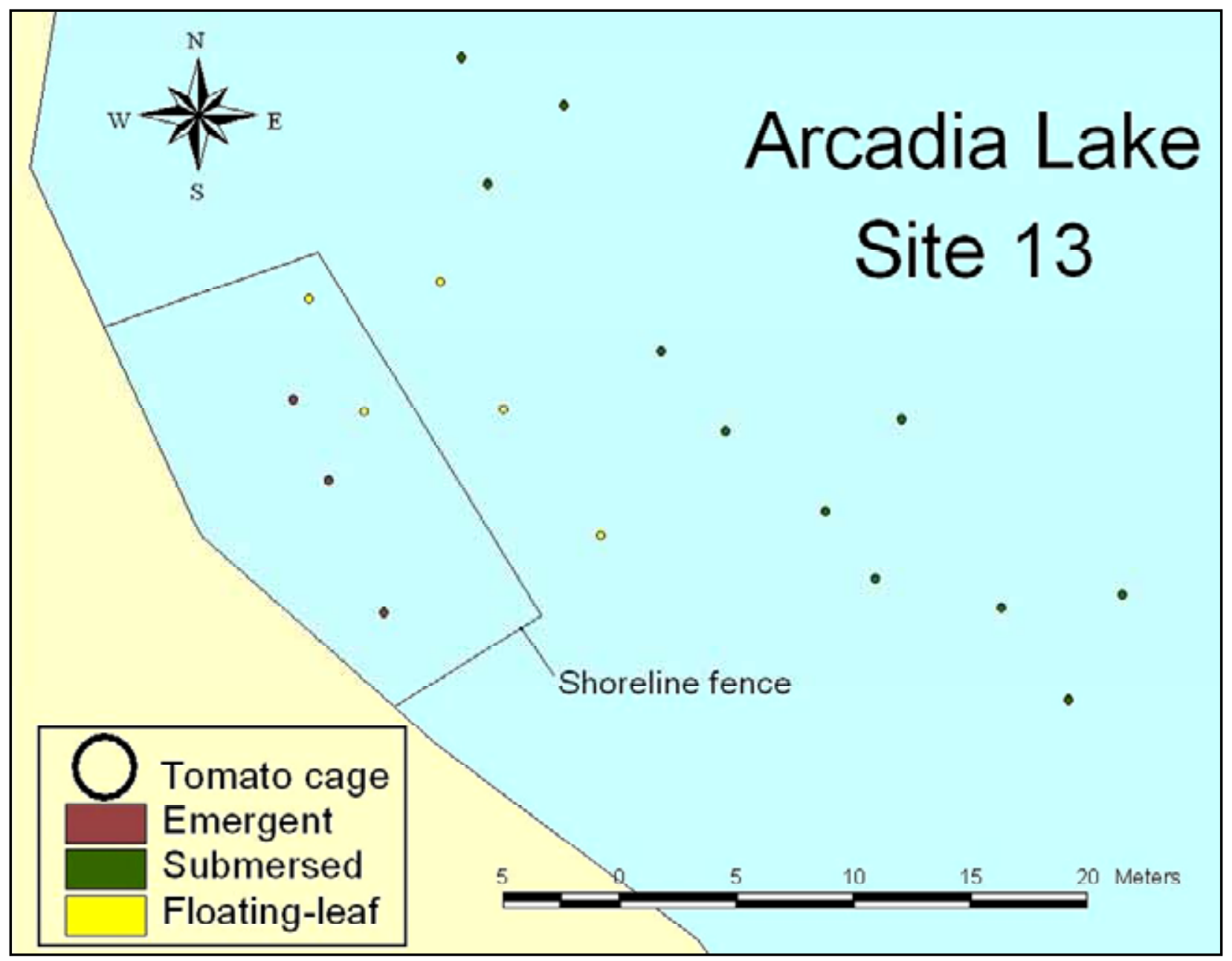

Figure 22. GPS mapping of aquatic plant colonies and protective exclosures was conducted at Site 13 in Arcadia Lake in June 1999 


\section{Site 14}

The initial design included 32 tomato cages planted with American lotus and American pondweed, elodea, sago pondweed, or water stargrass. By July 1997, few American lotus plants were surviving. Most submersed species exhibited high survival, except for sago pondweed, of which only one plant remained. Empty cages were replanted with the submersed species originally planted. By September 1997, no American lotus plants remained. American pondweed and water stargrass survival was good, but elodea and sago pondweed had not survived. Herbivory was evident in many remaining plants.

In June 1998, a shoreline fence was added, enclosing several of the existing tomato cages and planted with submersed and emergent species. By September 1998, most of the area behind the shoreline fence was dry, and about one-half of the cages were planted with water stargrass or American pondweed supported plants. Emergent species had survived, with most filling tomato cages, and some (flatstem spikerush, softstem bulrush, pickerelweed, and water willow) had spread to form colonies up to $2 \mathrm{~m}(6 \mathrm{ft})$ in diameter. Two each potted white water lily, water willow, and softstem bulrush were planted behind the shoreline fence.

By June 1999, most colonies had recovered from low-water conditions in 1998, and the site supported 25 plant colonies (Figure 23). The shoreline fence was not breached at this site. Colonies of American pondweed and water stargrass persisted in tomato cages, and American pondweed and white water lily

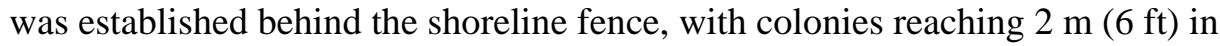
diameter. Softstem bulrush, bulltongue, flatstem spikerush, squarestem spikerush, water willow, and pickerelweed planted in tomato cages persisted, but spread had not occurred.

\section{Site 15}

The initial design included 12 tomato cages planted with American pondweed and 4 pens, with one-half of each pen planted with American pondweed, sago pondweed, elodea, or water stargrass. By July 1997, all American pondweed in tomato cages was surviving. Only American pondweed and water stargrass were observed in the pens. No replanting was undertaken at this time. By September 1997, American pondweed in tomato cages was gone. Dried stems and leaves were observed on all cages, and mortality was apparently a result of water level fluctuation. American pondweed and water stargrass were observed in pens, but coverage of both was sparse.

In June 1998, fences were added to tie the four pens together, producing a large, sectioned pen, thereby expanding the protected area at the site. Wild celery was planted in the large pen at that time. Tomato cages were added and planted with floating-leaved species. By September 1998, about one-half of the area protected by pens was dry. American pondweed and water stargrass persisted, with each pen exhibiting nearly 100-percent coverage, even in dry areas. A single colony of wild celery survived and spread within the pen to cover about 5 percent of the protected area. Floating-leaved species did not appear to survive the 


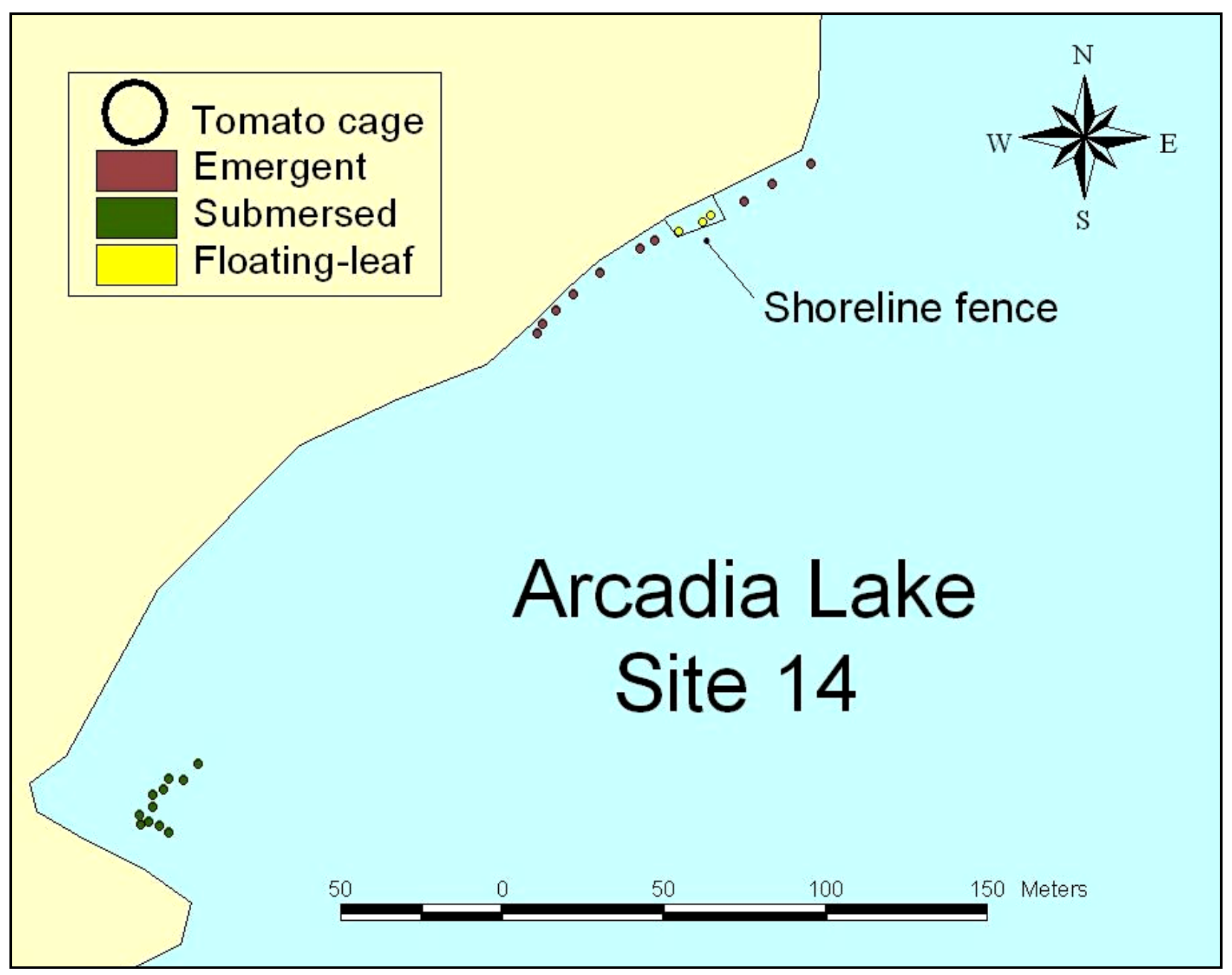

Figure 23. GPS mapping of aquatic plant colonies and protective exclosures was conducted at Site 14 in Arcadia Lake in June 1999

low-water period. Most tomato cages, although dry, continued to support American pondweed. Two American lotus apical tips and one pot each of white water lily and spatterdock were planted in the pens. Two each potted water willow and softstem bulrush were planted without protection along the shoreline adjacent to the pens.

By June 1999, most colonies had recovered from low-water conditions in 1998, and the site supported 17 plant colonies (Figure 24). The large pen was not breached at this site, which was completely filled with American pondweed and water stargrass. Colonies of American pondweed, water stargrass, and spatterdock persisted in tomato cages, and spread was observed, with colonies reaching $1 \mathrm{~m}$ (3 ft) in diameter. Softstem bulrush and water willow planted without protection had survived, and colonies averaged about $1 \mathrm{~m}(3 \mathrm{ft})$ in diameter. 


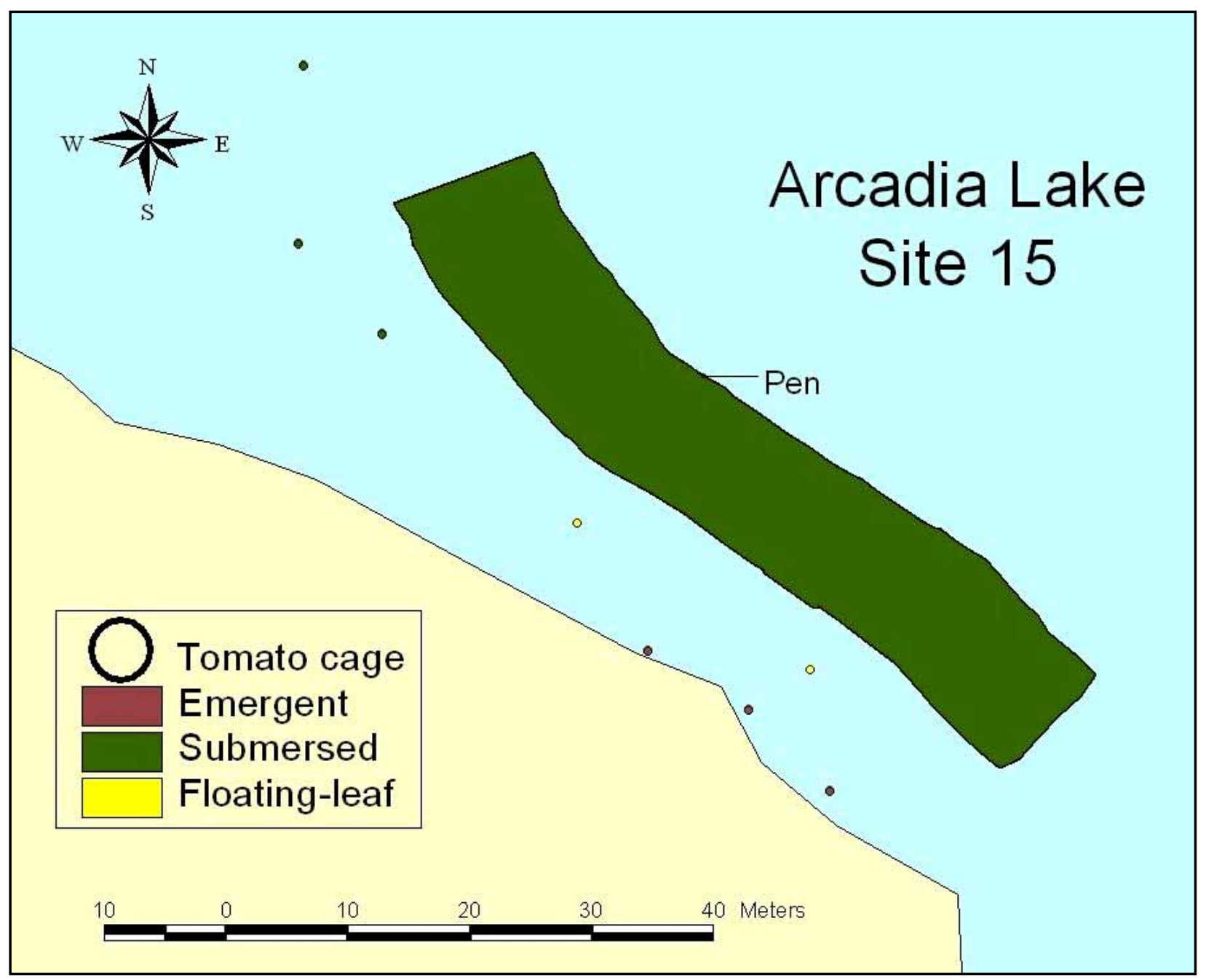

Figure 24. GPS mapping of aquatic plant colonies and protective exclosures was conducted at Site 15 in Arcadia Lake in June 1999 


\section{Conclusions}

As stated earlier, the objectives of this project were to: (a) evaluate the suitability of several emergent and submersed aquatic species for establishment in the lake; (b) ascertain effective methods for establishing desirable aquatic plant species; and (c) establish founder colonies of aquatic plants in several areas of the lake. All objectives were met in this project.

Founder colonies were established at most sites in Arcadia Lake by the end of the second growing season. Nearly one-half the species of aquatic plants tested survived, grew, and spread successfully within protective exclosures, and some thrived without protection. Of 24 species tested (including southern naiad and muskgrass), 11 were deemed suitable for establishment in Arcadia Lake. The other species remain marginal candidates, and different establishment techniques may improve the chances that any of those could become established in this lake. At some sites, new colonies of some species were developing near the original transplants, exhibiting the early stages of founder colony spread. These colonies not only withstood low-water conditions, but also were able to spread in the presence of grazers. Some species were not exhibiting spread beyond protective areas, but colonies had survived low-water conditions and intermittent periods of grazing (following breaches in cages).

Although several difficult challenges were encountered, these were overcome to produce established native aquatic plant founder colonies at several sites. Protection from herbivores, primarily common carp, was the greatest necessity in establishing plant colonies during this project. In nearly every case, and regardless of species, plants in protective exclosures survived transplanting and began to grow. When protective exclosures were breached by common carp or turtles, nearly all plant (species) colonies exhibited declines. In addition to identifying the need to protect plants in this (or similar) project(s), the results of this project also make clear the need to maintain protective exclosures over the long term.

Cove fences proved to be inefficient at protecting submersed species in Arcadia Lake, mostly because of continual breaches in the fences by floating debris and beavers, which allowed entry by common carp and turtles. Additionally, high-water levels during the winter and spring periodically allowed carp into these areas. Once inside a cove fence, carp were difficult to remove. Pens and shoreline fences proved much more reliable in protecting plants, with only high-water conditions or damage from floating debris leading to access by grazers. Beavers left these exclosures alone, perhaps because they did not interfere with the animals' activities: food supplies (trees) were often located in the 
backs of coves, behind the cove fences. Small-scale exclosures (tomato cages and orange cages) exhibited the greatest successes in protecting plants relative to all exclosures used in the study. However, these in themselves may have limited establishment and spread of plants because of the effects of constant abrasion against the mesh of the cage. A combination of small-scale and large-scale exclosures (tomato cages inside of pens or shoreline fences) appear to be the most effective means of establishing submersed and floating-leaved colonies in Arcadia Lake. Small-scale exclosures alone appeared to be adequate in establishment of emergent species.

Fluctuating water levels proved to be less a problem than initially expected in this project, except that these different levels occasionally served as a means for herbivores to enter otherwise protected areas (swimming over fences during periods of extremely high water). Most plant species survived low-water conditions that occurred during the second year. In fact, of all species tested, only three (wild celery, Illinois pondweed, and elodea) appeared to suffer extensively from desiccation. Moreover, of these three, only elodea was not found at all in the lake following low-water conditions, whereas the other two exhibited recovery at some sites.

Turbidity may have played a role in survival of submersed species at some of the deeper sites. During both years, pens installed at the most turbid sites (more open areas) exhibited the poorest establishment, and expansion of colonies lagged behind pens in more protected, clearer waters. Although depth differences between these sites may also be relevant, these differences were less than $0.25 \mathrm{~m}$ in most cases. It is more likely that poor light penetration reduced growth rates of transplants in more turbid waters, overall reducing transplant success and subsequent growth. Turbidity did not appear to influence establishment of floatingleaved or emergent species.

Wave action may have caused some problems in establishing plants. The failure of American lotus to establish from 10-cm (4-in.) potted plants is believed to have been caused by damage to leaves and stems as waves pushed them against the abrasive cage materials. Similar damage to other species, most notably American pondweed and water stargrass, was noted in smaller cages. One means to eliminate or reduce this problem appeared to be construction of larger-diameter tomato cages, reducing the probability that portions of the colony were at risk to such abrasive damage.

Overall, plant establishment techniques applied in this project have succeeded in establishing founder colonies in Arcadia Lake. These founder colonies can be sustained over time by maintaining protective exclosures and removing herbivores when breaches occur. As long as these founder colonies are well maintained, they will be able to exploit conditions for spread and natural establishment in other areas of the lake should occur. 


\section{References}

Barko, J. W., Hardin, D. G., and Matthews, M.S. (1982). "Growth and morphology of submersed freshwater macrophytes in relation to light and temperature,” Can . J. Bot. 60, 877-887.

Dibble, E. D., Killgore, K. J., and Harrell, S. L. (1996). “Assessment of fish-plant interactions.” Multidimensional approaches to reservoir fisheries management. L. E. Miranda and D. R. DeVries, eds., Amer. Fish. Soc. Symp. 16, 347-356.

Dick, G. O., Smart, R. M., and Keiser, E. D. (1995). "Turtles and their potential impact on aquatic plants in Guntersville Reservoir, Alabama,” Guntersville Joint Agency Project, Tennessee Valley Authority Technical Report.

Doyle, R. D., and Smart, R. M. (1993). "Potential use of native aquatic plants for long-term control of problem aquatic plants in Guntersville Reservoir, Alabama; Report 1, Establishing native plants,” Technical Report A-93-6, U.S. Army Engineer Waterways Experiment Station, Vicksburg, MS.

Doyle, R. D., Smart, R. M., Guest, C., and Bickell, K. (1997). "Establishment of native aquatic plants for fish habitat: Test plantings in two north Texas reservoirs," Lake and Reservoir Management 13, 259-269.

Gilliland, G. (1997). Personal communication. Oklahoma Department of Wildlife Conservation, Norman, OK.

James, W. E., and Barko, J. W. (1990). "Macrophyte influences on the zonation of sediment accretion and composition in a north-temperate reservoir," Arch Hydrobiol. 120, 129-142.

. (1995). "Effects of submersed macrophytes on sediment resuspension in Marsh Lake, Minnesota." Proceedings, $29^{\text {th }}$ annual meeting, Aquatic Plant Control Research Program, Miscellaneous Paper A-95-3, U.S. Army Engineer Waterways Experiment Station, Vicksburg, MS.

Smart, R. M., Barko, J. W., and McFarland, D. G. (1994). "Competition between Hydrilla verticillata and Vallisneria americana under different environmental conditions,” Technical Report A-94-1, U.S. Army Engineer Waterways Experiment Station, Vicksburg, MS. 
Smart, R. M., Doyle, R. D., Madsen, J. M., and Dick, G. O. (1996). "Establishing native submersed aquatic plant communities for fish habitat.” Multidimensional approaches to reservoir fisheries management. L. E. Miranda and D. R. DeVries, eds., American Fisheries Society Symposium 16, 347-356. 


\section{Appendix A 2001 Assessments}

\section{Sites Mapped}

In June 2001, Arcadia Lake was visited and several sites assessed to ascertain long-term success of the project. Five (5) of the fifteen (15) sites were mapped using the Global Positioning System (GPS) during the first day of assessments. Heavy rains that night and the following day raised lake water levels by about 1 $\mathrm{m}$ (3 ft), and although each was visited, complete assessments of the remaining 10 sights were not conducted.

\section{Condition of Sites}

In general, the sites appeared to be in one of two conditions:

a. Protective exclosures had been breached and/or degraded, and few, if any, plants remained visible at the sites. Sites 3 and 4 exhibited these conditions, and although most plants originally installed were no longer present, long-term establishment of at least one species had occurred. As an example, at Site 4, plant establishment was limited to a single colony of spatterdock, most of which remained protected by a ring cage (Figure A1). The shoreline fence and other cages at this site were damaged or missing, apparently from water flow through a drainage culvert located at the back of the cove. Three intact tomato cages, originally planted with American pondweed, remained at this site, but were empty. Crayfish grazing on plants had been a problem early on at Site 4, and likely contributed to poor success.

b. Some protective exclosures had been breached and/or degraded, but many remained intact, and plants were established both inside and outside cages at these sites. Sites 5, 6, and 7 exhibited these conditions, with multiple species exhibiting long-term establishment. As an example, at Site 6, plant establishment inside exclosures (tomato cages and pens) included all growth forms represented by 13 of the 22 (59 percent) species planted. Submersed forms included American pondweed, water stargrass, and southern naiad; floating-leaved forms included American lotus, white water lily, and spatterdock; and emergent forms included 


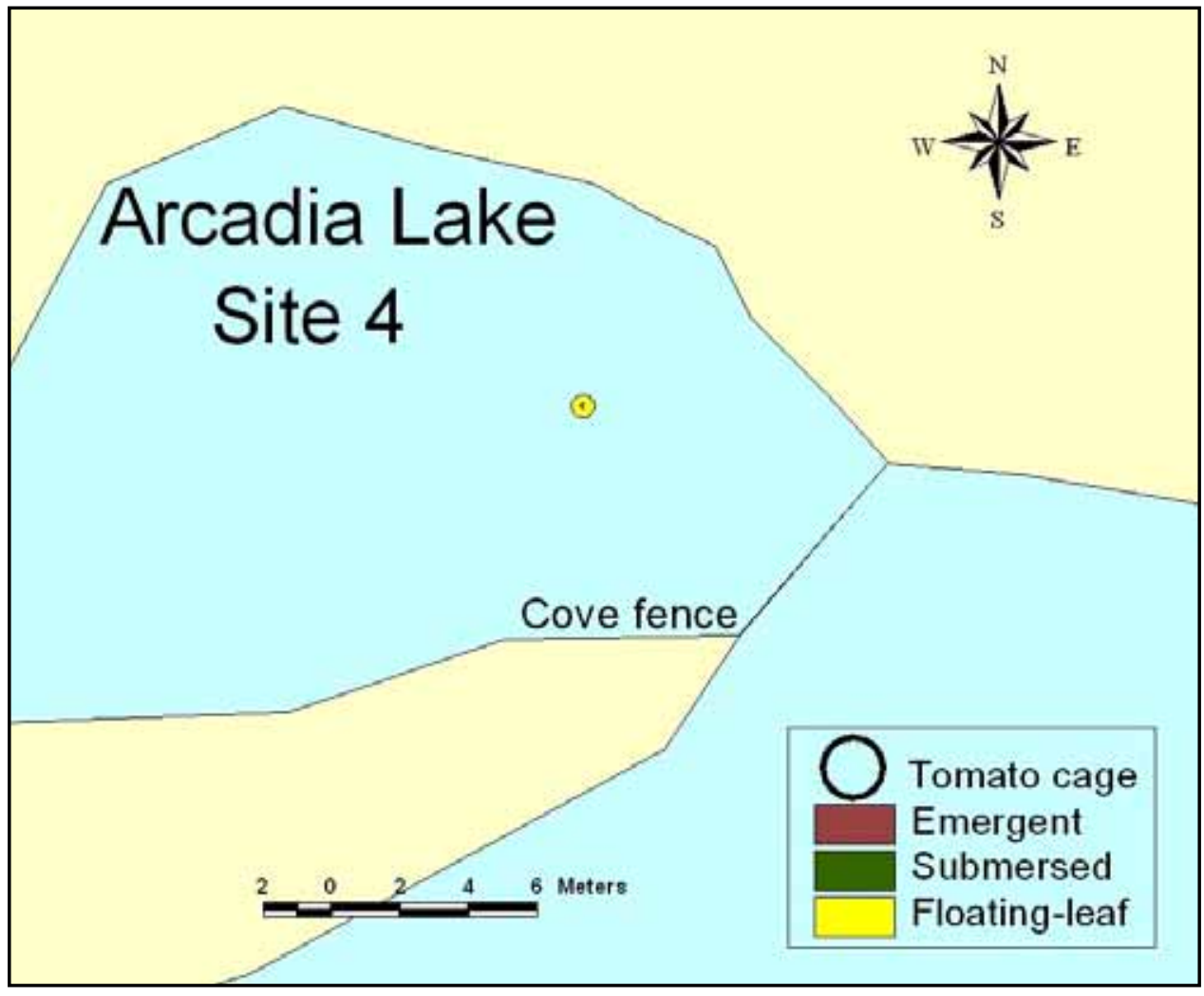

Figure A1. GPS mapping of aquatic plant colonies and protective exclosures was conducted at Site 4 in Arcadia Lake in June 2001. Although most of the protective exclosures were damaged or degraded, a single colony of spatterdock remained established at this site

water willow, pickerelweed, softstem bulrush, lizard's tail, flatstem spikerush, bulltongue, and arrowhead (Figure A2). Species that had spread beyond protective exclosures included American pondweed, water stargrass, American lotus, water willow, bulltongue, and arrowhead. When compared with colonies in June 1999, fewer species remained, although overall coverage had increased considerably, implying that spread from founder colonies was occurring in Arcadia Lake. 


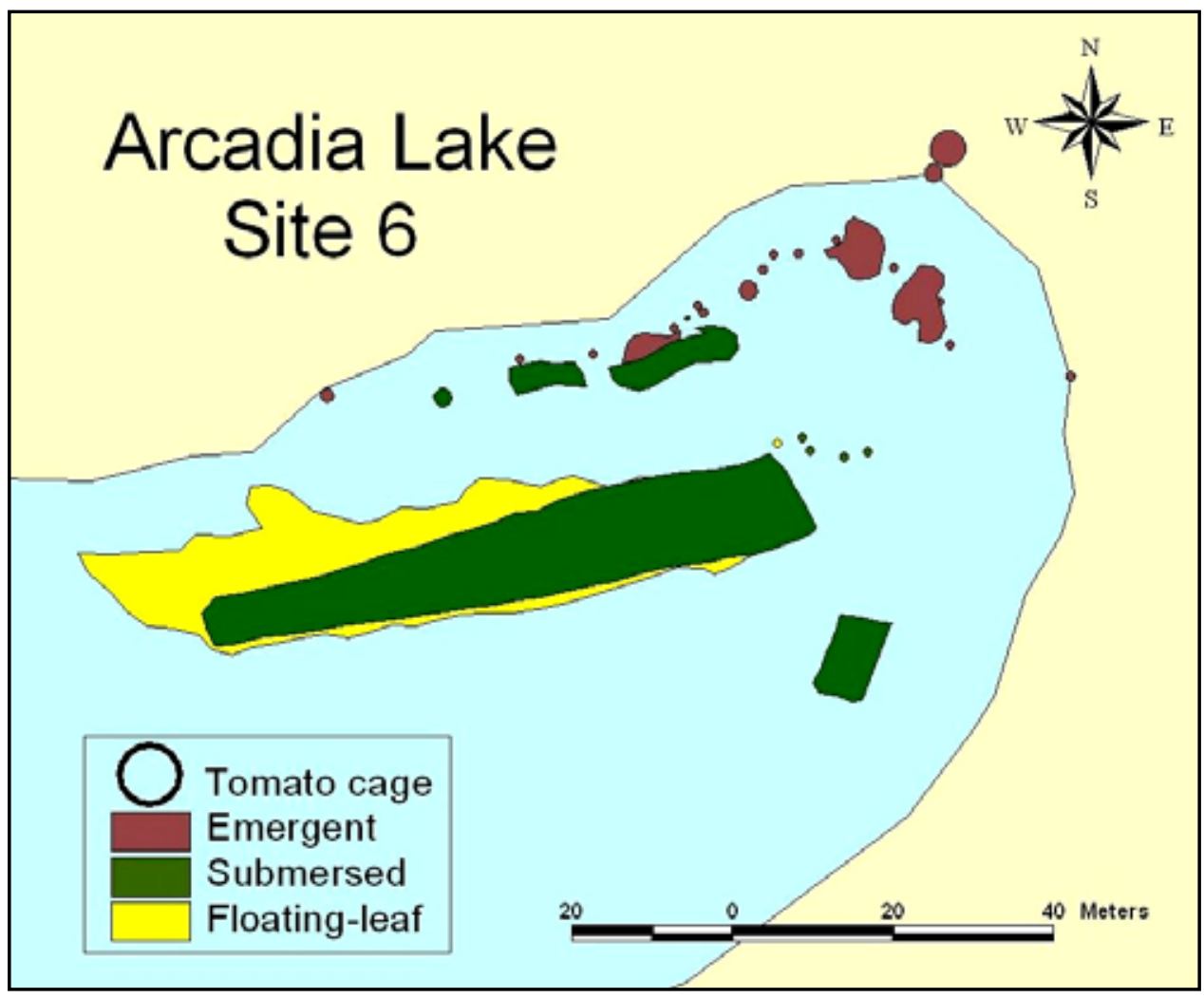

Figure A2. GPS mapping of aquatic plant colonies and protective exclosures was conducted at Site 6 in Arcadia Lake in June 2001 


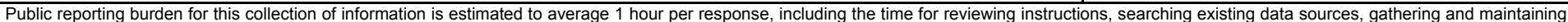

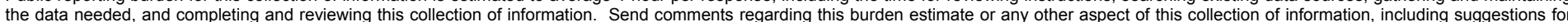

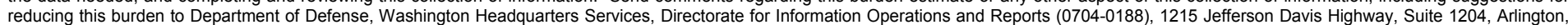

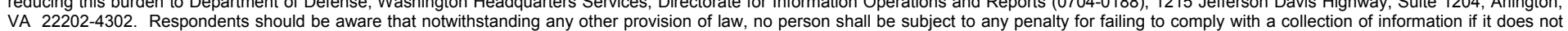
VA 22202-4302. Respondents should be aware that notwithstanding any other provision of law, no person shall be sube
display a currently valid OMB control number. PLEASE DO NOT RETURN YOUR FORM TO THE ABOVE ADDRESS.

\begin{tabular}{l|c}
$\begin{array}{l}\text { 1. REPORT DATE (DD-MM-YYYY) } \\
\text { May } 2004\end{array}$ & $\begin{array}{c}\text { 2. REPORT TYPE } \\
\text { Final report }\end{array}$ \\
\hline
\end{tabular}

\section{TITLE AND SUBTITLE}

Aquatic Vegetation Restoration in Arcadia Lake, Oklahoma: A Case Study

3. DATES COVERED (From - To)

5a. CONTRACT NUMBER

5b. GRANT NUMBER

5c. PROGRAM ELEMENT NUMBER

\section{AUTHOR(S)}

Gary Owen Dick, R. Michael Smart, Eugene R. Gilliland

\section{5d. PROJECT NUMBER}

5e. TASK NUMBER

5f. WORK UNIT NUMBER

33084

8. PERFORMING ORGANIZATION REPORT NUMBER

ERDC/EL TR-04-7

U.S. Army Engineer Research and Development Center

Lewisville Aquatic Ecosystem Research Facility

201 E. Jones Street

Lewisville, TX 75057

\section{SPONSORING / MONITORING AGENCY NAME(S) AND ADDRESS(ES)}

10. SPONSOR/MONITOR'S ACRONYM(S)

Headquarters, U.S. Army Corps of Engineers

Washington, DC 20314-1000

11. SPONSOR/MONITOR'S REPORT NUMBER(S)

\section{DISTRIBUTION / AVAILABILITY STATEMENT}

Approved for public release; distribution is unlimited.

\section{SUPPLEMENTARY NOTES}

\section{ABSTRACT}

Arcadia Lake is located within the metropolitan area of Oklahoma City and Edmund, in Oklahoma County, Oklahoma, about 2.4 km (1.5 miles) southwest of Arcadia, Oklahoma (Figure 1). Construction of the earth-filled dam was authorized by the Flood Control Act of 1970 and approved for construction by the Secretary of the Army for the purposes of flood control, water supply, and recreation. Construction was completed in 1986, and conservation pool was reached in 1989. The dam impounds a section of the Deep Fork River, with drainage coming principally from surrounding municipalities. The reservoir covers approximately 736 ha (1,820 acres) at an

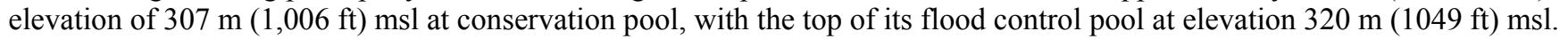

The overall objective of the project was to begin restoration of spawning and nursery fishery habitat for the sunfish family (largemouth bass, crappie, and bluegill) lost from flood control operations. When initially impounded, flooded terrestrial structure provided good habitat for the sunfish fishery. As flood control operations were implemented, habitat structure (primarily flooded tress and brush) degraded, leaving the lake poorly suited for this fishery. The loss of structure also contributed to increases in turbidity, further affecting the sunfish fishery.

(Continued)

\section{SUBJECT TERMS}

Aquatic herbivory

Aquatic plants

16. SECURITY CLASSIFICATION OF:

\begin{tabular}{|l|l|}
\hline a. REPORT & b. ABSTRACT \\
UNCLASSIFIED & UNCLASSIFIED \\
\hline
\end{tabular}

Aquatic plant establishment

Aquatic plant restoration

Aquatic vegetation establishment
Aquatic vegetation restoration Fish habitat

\section{Native aquatic plants \\ 17. LIMITATION 18 . NUMBER OF ABSTRACT OF PAGES \\ 19a. NAME OF RESPONSIBLE PERSON}

c. THIS PAGE

UNCLASSIFIED
60 19b. TELEPHONE NUMBER (include area code) 


\section{4. (Concluded)}

The specific objectives of the project were to (a) evaluate the suitability of selected native emergent, floatingleaved, and submersed aquatic species for establishment in the lake, (b) ascertain effective methods for establishing desirable aquatic plant species, and (c) establish founder colonies of aquatic plants in several areas of the lake. In addition to providing immediate nursery habitat for juvenile fish, these founder colonies were expected to provide propagules for natural spread to other areas of the lake. 